\title{
Los campesinos y la formación del Estado en el México del siglo XIX: Morelos, 1848-1858*
}

\author{
Florencia E. Mallon
}

E1 17 y 18 de diciembre de 1856, una banda de aproximadamente 30 hombres llevó a cabo una dramática incursión y múltiples asesinatos en las haciendas de Chiconcuac, Dolores y San Vicente, pertenecientes al ciudadano español Pío Bermejillo y localizadas en el distrito de Cuernavaca, hoy estado de Morelos. Según las versiones presentadas en el juicio que se siguió, estos hombres tomaron como rehén a un empleado español llamado Víctor Allende en los límites de la hacienda de Chiconcuac el 17 de diciembre, tocaron al portón de la casa grande y se les negó la entrada, pero un disparo y la voz asustada de Allende hicieron que el guardián sospechara; pasaron la tarde y la noche en los alrededores de la hacienda robando y saqueando y, después de cabalgar hasta Dolores, mataron a Allende.

A la mañana siguiente, entre las seis y las siete, entraron triunfalmente a la hacienda de San Vicente. Primero saquearon la casa grande y mataron a Juan Bermejillo, sobrino del propietario. Luego localizaron a Nicolás Bermejillo, hermano del dueño, y a otros dos trabajadores españoles escondidos en el trapiche. Cuando Bermejillo les ofreció dinero para salvar sus vidas pareció que aceptaban la oferta y escoltaron a los prisioneros de vuelta al purgar para buscar el dinero. Incapaz de encontrarlo, la banda regresó los prisioneros a la puerta del frente y los mató: otros dos empleados de la hacienda salvaron sus vidas insistiendo en que eran franceses y no españoles. Por fin dejaron la hacienda y cabalgaron hasta un cerro cercano, donde se distribuyeron el botín.'

Durante 48 horas el pánico se extendió por el distrito de Cuernavaca. Los españoles residentes en algunos de los pueblos y haciendas del área se fueron a la ciudad de Cuernavaca, más segura, pues corrian rumores de que los acontecimientos recientes eran parte de un plan generalizado para matar a los españoles del valle. De hecho algunos de los refugiados aseguraban que ya habían sido robados 0

- Political Power and Social Theory, vol. 7, JAI Press Inc., Madison (Wisconsin), 1988, pp. 1-54. Trad. E. Lastra.

1 El purgar era el edificio donde se ponía el jugo de caña para que se cristalizara. La versión del incidente presentada aquí está basada en los procedimientos de la corte reportados en Luis Aguilar y Medina, Defensa leída el 5 de agosto de 1858, en los estrados de la Exma. Tercera Sala de la Suprema Corte de Justicia, Imprenta de Manuel Castro, México, 1858; José María Casasola, Acusación fiscal que en la tercera sala de la Suprema Corte de Justicia pronunció el Sr. ministro fiscal de ella, Imprenta de A. Boix, México, 1858; José Antonio Bucheli, Sentencia pronunciada en Primera Instancia... (anexo), Imprenta de A. Boix, México, 1858. El hecho de que Juan Bermejillo fuera el sobrino del propietario fue reportado por el cónsul francés en México, Alexis de Gabriac. Véase Lilia Díaz (ed.), Versión francesa de México: informes diplomáticos (1853-1858), vol. 1, El Colegio de Méxioo, México, 1963, p. 379. [Las cursivas en español aparecen así en el original. N.T.] 
amenazados. El encargado de negocios de la legación española, Pedro Sorela, comenzó de inmediato a ejercer presión sobre el gobierno mexicano y envió por su cuenta a un investigador a Cuernavaca para que averiguara qué había pasado. ${ }^{2}$

En las dos semanas siguientes, conforme la polvareda se asentaba, la versión española de los sucesos se volvió cada vez más compleja. En la segunda nota diplomática acerca del incidente, Sorela exponía la posición de su gobierno al insistir en que, según fuentes fidedignas, los crímenes de San Vicente se habían perpetrado al grito de batalla "|Vivan Âlvarez y Villalva y mueran los españoles!" Concluía diciendo que al menos seis de los oficiales de la división de Alvarez habían estado implicados en amenazas o campañas contra ciudadanos españoles. ${ }^{3}$ A finales de diciembre, los representantes del gobierno español habían decidido que los asesinatos de la hacienda de San Vicente eran parte de un plan general, y que este plan para acabar con los españoles estaba dirigido por la división del ejército liberal comandada por Juan Álvarez, uno de los dirigentes más importantes y prestigiosos de la revolución de 1855 .

El escenario estaba listo para la confróntación y ésta no tardó en llegar. E1 10 de enero Sorela informó al góbìerno mexicano que romperían relaciones diplomáticas si el àsunto no quedaba aclarado por completo en una semana. El 19 de enero solicitó formalmente su pasaporte para abandonar el país. ${ }^{4}$ En un mes el gobierno español había enviado otros cinco buques de guerra para reforzar su armada cubana que constaba de 25 , y las fuerzas combinadas del ejército y la marina estacionadas en el Caribe estaban listas para invadir México con el fin de "proteger la retirada de la legación [española] y las vidas y haciendas de los súbditos españoles en caso de que se vieran amenazadas de alguna manera". ${ }^{5}$ Entre febrero y marzo los periódicos españoles adquirieron un tono febril, exigiendo la guerra con México para salvar el honor de España. ${ }^{6}$ Mientras tanto el prominente político liberal José María Lafragua, que había sido enviado para negociar con el gobierno español, se persuadía cada vez más de que el gobierno mexicano había hecho todo lo posible para satisfacer a España, incluso llevar a juicio a los culpables tan pronto como fue posible, y que cualquier animosidad de carácter privado que existiera entre ciudadanos mexicanos y españoles no podía ser imputable al Estado mexicano o convertida en un asunto diplomático entre los dos países. ${ }^{7}$

¿Por qué este incidente en especial produjo un enfrentamiento - tan grande? En el plano diplomático los dos países interpretaron el

2 Acerca del pánico, rumores y reclamaciones de los refugiados, véase AHDN (Archivo Histórico de la Defensa Nacional, México), XI/481.3/6867: "Carta del general Benito Haro al ministro de Guerra", 20 de diciembre de 1856. Sobre la actitud de Sorela, véase El Estandarte Nacional, 22 de enero de 1857, p. 1.

3 Pedro Sorela, "Segunda nota diplomática del cónsul de España en México", Crónica Oficial, 28 de diciembre de 1857, p. 3.

- El Estandarte Nacional, 22 de enero de 1857, p. 1. Véase también AHDN, XI/481.3/6867: "Nota reservada del ministro de Relaciones Exteriores al ministro de Guerra, sobre el rompimiento de relaciones con España", 22 de enero de 1857.

5 "Circular del gobierno español del 17 de febrero de 1857", El Estandarte Nacional, 3 de abril de 1857, p. 1 .

6 lbid.

7 Crónica Oficial, 25 de diciembre de 1857, p. 3; Ramón Sánchez Flores, José María Lafragua. Vida y obra, Secretaría de Cultura, Puebla, 1985, p. 125. 
caso de modo diametralmente opuesto. Para España, el hecho de que el gobierno mexicano no quisiera actuar en contra de Álvarez a pesar de la clara complicidad de sus oficiales en los asesinatos, sólo probaba que el gobierno estaba involucrado en una campaña antiespañola; esto era un acto de enemistad. Desde el punto de vista mexicano, la complicidad de Álvarez no se había probado y los representantes de España se habían excedido en sus atribuciones desde el principio, pues se habian negado a permitir que el sistema judicial mexicano siguiera su curso normal. Esto hizo del asunto una cuestión de soberanía nacional. ${ }^{8}$

No obstante, para ninguna de las partes se trataba de un caso aislado; desde la década de 1820, España había realizado una campaña de espada desenvainada en un intento neocolonialista por mantener su influencia en México, mientras que diversos gobiernos mexicanos se habían visto comprometidos en actos hostiles hacia ciudadanos españoles como un avance en el intento de cortar las ataduras coloniales. ${ }^{9}$ Por lo tanto, una de las cosas que demostraré en este trabajo es que ambas partes reaccionaron de forma tan violenta al incidente de 1857 porque sirvió a los dos países para romper una serie de tensiones que habían comenzado con la guerra de Indepen. dencia de 1810.

También mostraré que los aspectos diplomáticos del incidente de 1857 eran tan sólo la punta del iceberg. Bajo la superficie había pro-fundos conflictos sociales y políticos acerca de quién debía manifestarse en definir el carácter del Estado mexicano y el futuro de la nación mexicana; estos conflictos implicaban no sólo a las facciones de las clases dominantes diferenciadas regional y políticamente, sino también a sectores importantes del campesinado y de las clases medias provincianas. Y los españoles, como se puso de manifiesto, estaban involucrados hasta el fondo en estos conflictos, algo que en sí los ponía fuera de la esfera estrictamente diplomática.

La incursión a las haciendas de Dolores, Chiconcuac y San Vicente nos proporciona, por consiguiente, una ventana desde donde observar las luchas que se libraron para la formación del Estado mexicano a mediados del siglo xix. La razón fundamental es que involucra a los principales actores del drama social que a finales de los sesenta y principios de los setenta generarían los inicios de un Estado nacional viable: aparatos estatales en parte heredados del periodo colonial, clases dominantes muy divididas en facciones y un movimiento popular fuerte y variado con profundas raíces en el campo. No obstante, las interacciones y los enfrentamientos entre los actores y las estructuras forjaron la trayectoria histórica específica que México siguió desde la neocolonia hasta el Estado-nación. En este proceso de la formación nacional y del Estado serían cruciales

- Acerca de la posición española, véase El Estandarte Nacional, 24 de enero de 1857 , p. 1; 3 de marzo de 1857, p. 1; 31 de marzo de 1857, p. 1. Acerca de la posición mexicana, además de las fuentes citadas en la nota 7, véase El Estandarte Nacional, 22 de enero de 1857, p. 1; 23 de enero de 1857, p. 1; Crónica Oficial, 21 de diciembre de 1856 , p. 3.

9 La historia de las relaciones mexicano-españolas en la primera mitad del siglo xIX será vista con detalle más adelante. Para tener una visión general, véanse Romeo Flores Caballero, La contrarrevolución en la independencia: Los españoles en la vida política y económica de México (1804-1838), El Colegio de México, México, 1969; Harold D. Sims, La expulsión de los españoles de México (1821-1828), Fondo de Cultura Económica, México, 1974. 
los años que van de la revolución liberal al principio del porfiriato (de 1850 a 1876, aproximadamente). Las soluciones que los actores de esta historia hallaron para las contingencias específicas que enfrentaron durante estas dos y media décadas, establecieron los parámetros dentro de los cuales iba a desarrollarse el Estado mexicano en sus formas más maduras: la porfirista y la posrevolucionaria. Y en Morelos, el incidente de 1857 proporcionó "un ensayo con vestuario" del drama que se habría de representar, con miles de variaciones, durante los siguientes 20 años, a lo largo de la formación social mexicana.

En el contexto de los debates recientes acerca de la naturaleza del Estado mexicano, el análisis de una instancia históricamente específica en la formación del Estado es de especial importancia. Después de que la matanza de estudiantes en Tlatelolco en 1968 puso de relieve de modo dramático los límites de la democracia en México, entre los especialistas y otros intelectuales comienzan a adquirir vigencia nuevas perspectivas acerca de la historia mexicana y de la política actual. Un elemento unificador clave de estos puntos de vista ha sido la continuidad del autoritarismo. Desde el triunfo de Iturbide en 1821, hasta la incursión de las reformas liberales de mediados de siglo en tierras indias, la aparente estabilidad del porfiriato, la consolidación del Estado posrevolucionario contra las protestas de las masas campesinas del occidente de México en los años veinte de este siglo, el tema común que corre a través de toda la historia moderna mexicana ha sido la expansión del poder del Estado en contra de la autonomía o de las aspiraciones de las masas. En este contexto, muchos ven ahora las revoluciones de 1855 y de 1910 como momentos en los que el Estado fue particularmente exitoso en el avance del proceso de consolidación y concentración de poder. Por todo, el asunto vuelve comprensible el refinamiento del regateo político o caciquismo y no los movimientos sociales que le sirven de telón de fondo. Quizá John Womack lo sintetiza mejor en su reciente escrito: "Los grandes asuntos fueron asuntos de Estado. . . ya no más revolución social, sino manipulación política. Y la interpretación aquí es primariamente una historia política. Carece de movimientos sociales porque a pesar de que su existencia era importante, su derrota o subordinación interesaban más." 10

10 John Womack Jr., "The mexican revolution, 1910-1920", en Leslie Bethell (ed.) The Cambridge history of Latin America, Cambridge University Press, Cambridge y Nueva York, 1986, vol. 5, p. 82. La bibliografía sobre historia de México que es importante resulta muy vasta para citar siquiera una muestra representativa. Un buen lugar para comenzar, además del ya citado de Womack, son los ensayos de Jan Bazant ("Mexico from independence to 1867", 1985) y Friedrich Katz ("Mexico restored republic and porfiriato, 1867-1910", 1986) que también aparecen en The Cambridge history of Latin America (vols. 3 y 5 , respectivamente) y sus correspondientes ensayos bibliográficos. Algunas importantes e influyentes perspectivas revisionistas son: Héctor Aguilar Camín, La frantera nómada: Sonora y la revolución mexicana, Siglo xxı Editores, México, 1977; David A. Brading, Caudillo and peasant in the mexxican revolution, Cambridge University Press, Cambridge y Nueva York, 1980; Peter Calvert, "The mexican revolution: Theory or Fact?". The Journal of Latin American Studies, núm. 1, 1969, pp. 51-68; Barry Carr, "Las peculiaridades del norte mexicano, 1880-1927: Ensayo de interpretación", Historia Mexicana, vol. 22, núm. 3, 1973, pp. 320-346; John H. Coatsworth, "Los orígenes del autoritarismo moderno en México", Foro Internacional, vol. 16, núm. 2, 1975, pp. 205-232; Adolfo Gilly (comp.), Interpretaciones de la revolución mexicana, Editorial Nueva Imagen, México, 1979; y La revolución interrumpida. México, 1910-1920: Una guerra campesina por la tierra y el poder, Ediciones El Caballito, 1971; Alan Knight, The mexican revolution, Cambridge University Press, Cambridge, 1986, 2 vols.; Jean Meyer, La Cristiada, Siglo XXI 
De cierto estas revisiones han servido como un antídoto adecuado contra las versiones santificadas de la historia oficial, en las que el tema principal era siempre el progreso de México hacia la democracia, sobre todo con mucho éxito bajo la tutela del partido revolucionario oficial. No obstante, algunos especialistas se han dejado llevar por la inercia y, en su ansia por mostrar el fracaso de los movimientos de masas y de la democracia, también han desechado la influencia o autonomía de los movimientos populares. ${ }^{11} \mathrm{Al}$ hacer esto, aun cuando nos han llevado más allá de falsos idealismos, les falta incorporar las ideas de la nueva generación de historiadores sociales, que durante los últimos 10 años han estado investigando a Latinoamérica "desde abajo". El resultado ha sido otra reproducción del viejo dualismo entre sociedad y política, irónicamente compartido por la "nueva historia social" y otras formas más tradicionales de historia política, militar y diplomática.

Las recientes demandas entre los historiadores sociales y políticos de integrar los métodos y las perspectivas, ${ }^{12}$ son de especial importancia en el caso de México. Como intento de historia política, militar y diplomática desde abajo, este trabajo es un primer paso hacia la reapertura del diálogo entre los especialistas que se dedican a estudiar el Estado y los que se ocupan de la gente común. Porque, como espero demostrar en las siguientes páginas, la formación del Estado no fue sólo el producto de las luchas con y entre las clases dominantes y las potencias extranjeras, sino también un proceso en el que estuvieron estrechamente involucrados los campesinos, los pequeños propietarios y mucha gente más que conformaba el grueso de la población mexicana del siglo xIX. Esta implicación no era simplemente en un sentido - manipulación, cooptación y derrota-, sino un conjunto de conflictos de rica textura en el que todas las clases y grupos étnicos lucharon para encontrar aliados y definir sus metas políticas y sociales. Que la lucha fue desigual, no es necesario decirlo, pero los resultados no siempre estuvieron dados a priori, y las acciones de los vencidos lo mismo que las de los victoriosos ayudaron en última instancia a moldear los contornos del Estado-nación.

En este punto ya debería estar claro que haré un intento sumamente revisionista de la comprensión del Estado mexicano, aunque

Editores, México, 1974, 3 vols.; Esperando a Lozada, El Colegio de Michoacán, Zamora (Michoacán), 1984; y Problemas campesinos y revueltas agrarias, 1821-1910, SepSetentas, México, 1971; José Luis Reyna y Richard S. Weinert (comps.), Authoritarianism in Mexico, Institute for the Human Issues, Filadelfia, 1977; John Tutino, From insurrection to revolution in Mexico: social bases of agrarian violence, 1750 1940, Princeton University Press, Princeton, 1986; y por último, otro trabajo de Womack, "The mexican economy during the revolution, 1910-1920: historiography and analysis”, Marxist Perspectives, vol. 1, núm. 4, 1978, pp. 80-123.

1 Véanse por ejemplo, Aguilar Camín, op. cit.; Brading, op. cit.; Calvert, op. cit.; Lorenzo Meyer, "Historical roots of the authoritarian state in Mexico", en J.S. Reyna y R.S. Weinert, op. cit., pp. 3-22. No todos los especialistas están de acuerdo en este punto y todavía continúa un animado debate. Véanse las obras citadas de Gilly, Knight y Tutino.

12 Una de las primeras advertencias sobre tal reintegración fue hecha por $\mathbf{E}$.J Hobsbawm, "From social history to the history of society", Daedalus, vol. 100, núm. 1, 1971, pp. 20-45; y Jacques Le Goff, "Is politics still the backbone of history?" Daedalus, vol. 100, núm. 1, pp. 1-19. Una discusión reciente sobre estos temas en América Latina es la de William B. Taylor, "Between global process and local knowledge: An inquiry into early Latin American social history", Reliving the past: the worlds of social history, comp. Olivier Zunz, University of North Carolina, Chapel Hill, 1985, pp. 115-190. 
este intento no carece por completo de precedentes. ${ }^{13}$ Las implicaciones de tal aproximación son complejas, no sólo para México, sino para las teorías del Estado en general. Todavía a esta altura del trabajo no es mi propósito meterme en un atolladero discutiendo estas implicaciones. Si asi lo hiciera, desperdiciaría precisamente el aspecto más innovador de este escrito, a saber: el uso de un incidente específico para delinear empíricamente las interacciones entre las estructuras y las fuerzas sociales durante un lapso particular de la historia. Una vez que haya unido todos los hilos relativos a la incursión de Dolores, Chiconcuac y San Vicente, concluiré por mostrar las implicaciones teóricas más importantes de mi estudio.

\section{Los protagonistas históricos: el Estado mexicano}

Regresemos a la incursión y a los asesinatos de diciembre de 1856 y a la confrontación diplomática posterior. Es obvio que uno de los participantes más prominentes en estos acontecimientos fue el Estado mexicano. Desde los primeros años de la década de $1850 \mathrm{el}$ Estado había permanecido en un proceso de grandes cambios. La guerra mexicano-americana (1846-1848), durante la cual México había perdido casi la mitad de su territorio, causó una crisis profunda entre los intelectuales y políticos mexicanos. ${ }^{14}$ Por primera vez desde la independencia, un grupo de liberales llegaría al poder en 1855 con la revolución de Ayutla y objetaría radicalmente la naturaleza del Estado mexicano, tratando de institucionalizar y diferenciar su estructura. Los profundos y violentos conflictos que resultaron de estas pretendidas reformas habrían de establecer el escenario de la lucha civil para la próxima generación.

Los historiadores que estudian la colonia están de acuerdo en que el Estado colonial mexicano era fuerte en dos aspectos básicos: 1) era capaz de mantener los ingresos del erario fluyendo del virreinato a España, y 2) ejercía suficiente control sobre regiones y sectores claves de la economía para conservar un flujo constante de productos de exportación, a pesar de los intensos conflictos y contradicciones sociales subyacentes. Pero en ningún momento, sin embargo, el Estado colonial consiguió establecer una hegemonía absoluta sobre todo el territorio de la Nueva España. ${ }^{15}$ Y hablando de la relación del go-

13 Si se desea consultar trabajos que examinen el papel del conflicto social en la formación de otros estados latinoamericanos, véanse: Óscar Oszlak, "La conquista del orden político y la formación histórica del Estado argentino", Estudios Cedes, vol. 4, núm. 2, 1981; y "Formación histórica del Estado en América Latina: Elementos teórico-metodológicos para su estudio", Estudios Cedes, vol. 1, núm. 3, 1978; Maurice Zeitlin, The civil wars in Chile. (Or the bourgeois revolutions that never were), Princeton University Press, Princeton, 1984. Los intentos de examinar el papel del conflicto social en la organización o cambio del Estado mexicano incluyen a: Roger Bartra, "La revolución domesticada: Del bonapartismo pequeño-burgués a la institucionalización de la burguesía", Historia y Sociedad, 2a. época, vol. 6, verano de 1975, pp. 13-30; Arnaldo Córdova, La política de masas del cardenismo, Ediciones Era, México, 1974; Nora Hamilton, The limits of state autonomy, Princeton University Press, Princeton, 1982; Felipe Leal, "The mexican State: 1915-1973. A historical interpretation", Latin American perspectives, vol. 2, núm. 2, 1975, pp. 48-63; y México: Estado, burocracia y sindicatos, Ediciones El Caballito, México, 1975.

14 La mejor discusión de esta crisis sigue siendo Charles A. Hale, Mexıcan liberalism in the age of Mora, 1821-1853, Yale University Press, New Haven, 1968.

15 Acerca de la discusión del Estado colonial mexicano, véase específicamente John Coatsworth, "The limits of colonial absolutism: the state in eighteenth century 
bierno central con la administración local de las diversas regiones del virreinato, como la de 1695 y con más fuerza durante todo el siglo xviII, Marcello Carmagnani ha identificado una tendencia que él denomina "desadministración”: la dramática reducción de las rentas públicas dedicadas a la administración local y el concomitante aumento de la autonomía de las elites y autoridades locales. Esta fractura de los centros de poder, apunta Carmagnani, aunque tuvo sus orígenes en la política del Estado colonial, continuó durante el siglo xIX y constituyó uno de los problemas políticos centrales que tuvo que enfrentar el recién independizado pais. ${ }^{16}$

Con la decapitación del Estado colonial durante la guerra de independencia, México quedó como una formación social aún más desunida y balcanizada. La forma específica que tomaron las guerras, durante las cuales la política de la contrainsurgencia realista tendía a dejar la defensa en manos de la milicia local, ${ }^{17}$ había concentrado el poder en las regiones'y principalmente en las personas de los oficiales militares realistas e insurgentes que en verdad habían luchado; esto alentó no sólo la regionalización de la milicia, sino también la de las lealtades que se desarrollaban hacia los caudillos.

La independencia mexicana se consumó en 1821 bajo los auspicios de Agustín de Itürbide, uno de los caudillos realistas a cargo de la campaña de la contrainsurgencia, y constituyó un compromiso entre los leales y los oficiales insurgentes con bases de apoyo en diferentes partes del territorio mexicano. Durante las siguientes tres décadas la política mexicana se convirtió en una serie de maniobras para obtener una posición entre estos distintos caudillos con diversos distritos electorales. En estos años políticamente conflictivos la presidencia cambió de manos 14 veces. En cada caso el patrón de cambio fue similar: un caudillo militar hacía una alianza con un político o intelectual, emitía una declaración política o pronunciamiento y, después de haber ocupado triunfalmente la ciudad de México, él y su aliado eran declarados presidente y vicepresidente por el Congreso.

Una vez en control de la presidencia, no obstante, cada alianza caudillo-intelectual se daba cuenta de que era imposible llevar a cabo su política. En efecto, el Estado estaba compuesto de algo más que el ejecutivo y la milicia, y cada nuevo presidente encontraba necesario negociar constantemente con los caudillos que controlaban otras regiones. Como consecuencia se hicieron pocos procesos en la diferenciación o institucionalización de las estructuras del Estado que iban más allá de la presidencia, excepto por el creciente número de burócratas y de militares, que obtenian sus puestos como recompensa por apoyar al caudillo en el poder; incluso éstos no tenían

Mexico", en Essays in the political, economic, and social history of colonial Latin America, comp. Karen Spalding, University of Delaware Latin American Studies Program, Newark, 1982; William B. Taylor, Drinking, homicide ana rebellion in a colonial mexican village, Stanford University Press, Stanford, 1979.

16 Marcello Carmagnani, "Regionalism and the central government of Mexico during the nineteenth century", ponencia presentada en el Woodrow Wilson Center, 1984, y "Territorialidad y federalismo en la formación del Estado mexicano", inédito, s.f., pp. 11-13.

17 Brian Hamnett, "Royalist counterinsurgency and the continuity of rebellion: Guanajuato and Michoacan, 1813-1820", Hispanic American Historical Review, vol. 62, núm. 1, 1982, pp. 19-48. 
permanencia porque cambiaban regularmente con cada cambio de ejecutivo. ${ }^{18}$

Esta contradicción entre el casi inexistente Estado central y los fuertes bloques regionales de poder se reflejaba también en la política fiscal del Estado. Ya fueran federalistas o centralistas, los gobiernos de la primera mitad del siglo xIx lucharon por captar suficientes impuestos para mantenerse a flote. En especial durante el primer periodo federalista, el gobierno se apoyaba en las rentas públicas normales y en el supuesto derecho a un contingente, o contribución global, de cada uno de los estados. Pero los dineros que se otorgaban al gobierno federal mediante el contingente casi desaparecieron y, según Carmagnani, "los estados empobrecieron al Estado central precisamente para impedir su operación". El resultado fue una necesidad creciente de prestar dinero para cubrir los gastos corrientes; después de que el gobierno no pagó los préstamos ingleses en 1827, se vio forzado a apoyarse cada vez más en préstamos a corto plazo y elevados intereses, provenientes de un grupo local de prestamistas o agiotistas.

A pesar de que entre 1835 y 1846 los gobiernos centralistas establecieron formalmente un sistema muy impresionante de recaudación de impuestos, en la práctica no fue efectivo para tener acceso al erario. Los costos crecieron de manera dramática en esos años, en especial el pago de la deuda y en la recaudación de nuevos impuestos; sobre todo en este renglón, las dificultades del gobierno pusieron de manifiesto cuán complejo era evadir los bloques locales de poder. Por eso al final, todos los gobiernos de la primera mitad del siglo XIX se vieron forzados a apoyarse una y otra vez en prestamistas locales $y$, haciendo crecer el endeudamiento público, impidieron además la institucionalización de estructuras estatales efectivas. Las consecuencias de tal círculo vicioso son claras por el hecho de que en el periodo 1830-50, entre 80 y $90 \%$ del presupuesto del gobierno central se iba en pagar a la milicia y los intereses de la deuda pública. ${ }^{19}$

Alrededor de la década de 1840 el Estado mexicano seguía siendo en esencia el mismo cascarón que había sido después de la guerra de independencia en la primera década del siglo xıx; en el ámbito local de la formación social mexicana, gobernaba a la sociedad civil un complejo y encubierto conjunto de regulaciones e instituciones heredadas del periodo colonial. Haciendo alianzas estratégicas con estas instituciones locales y con las fuerzas sociales, los caudillos regionales centralizaron y reprodujeron su poder. Cualesquiera que fuesen sus intenciones iniciales, cada nueva coalición que entraba al palacio nacional se encontraba con que la permanencia allí significaba hacer las paces con estos bloques de poder preexistentes. Las dificultades fiscales también impedían a cada nueva coalición tener acceso efectivo a los recursos que podrían haber cambiado la situación. Todo el proceso significaba conflictos constantes y guerra civil; entonces vino la guerra con Estados Unidos.

18 Esta descripción de la política posterior a la independencia se basa en una serie de fuentes entre las que se encuentran: Carmagnani, "Regionalism...", op. cit., William L. Sherman y Michael C. Meyer, The course of mexican history, 2a. ed., Oxtord University Press, Nueva York, 1983; Jan Bazant, $A$ concise history of Mexico, 1805-1940, Cambridge University Press, Londres y Nueva York, 1977, pp. 30-61.

19 Carmagnani, "Regionalism. . ", op. cit., pp. 6-7. La cita textual está en la p. 7. 
La crisis intelectual y política causada por la ignominiosa derrota de México forzó por fin a la ruptura permanente del statu quo del periodo 1821-48. En 1854, un grupo de liberales nuevamente unificados objetó que fuera legítimo el que Antonio López de Santa Anna ocupara por quinta vez la silla presidencial. Redactado por el venera. ble caudillo del sur Juan Álvarez con la ayuda de algunos liberales que eran intelectuales prominentes, el Plan de Ayutla trataba sólo el problema de la centralización del poder y fue por tanto un típico pronunciamiento. El resultado del movimiento iniciado en Ayutla, sin embargo, probaría ser algo muy diferente. Entre octubre de 1855, cuando el recién electo presidente interino Juan Álvarez escogió su gabinete, y diciembre de 1858 , cuando los conservadores retomaron la ciudad de México, se establecieron las bases institucionales para la transformación del Estado mexicano. ${ }^{20}$

Dadas las divisiones y tensiones que afectaban la sociedad y la política mexicana, no es sorprendente que cuando tomaran el poder los dirigentes liberales estuvieran a su vez divididos en diversas líneas ideológicas, sociales y políticas. Desde el punto de vista social, la principal ruptura estaba entre los miembros más establecidos de la elite, como terratenientes, comerciantes y algunos militares, y las menos prósperas clases medias urbanas o provincianas, en especial jóvenes abogados y burócratas de nivel inferior. ${ }^{21}$ Ideológicamente, la separación se establecía entre los liberales radicales y los moderados, llamados "puros" y "moderados". Atendiendo a lo político, la principal diferencia estaba en la estrategia: cuál era la mejor manera de llevar a cabo todos los cambios institucionales sobre los que la mayoría de los liberales estaban de acuerdo.

A pesar de que se consideraban a sí mismos liberales, los puros y los moderados interpretaban el contenido de la doctrina liberal de manera muy diferente; mientras ambos grupos estaban de acuerdo en que el único camino para hacer una verdadera reforma en el Estado mexicano era atacando los intereses particulares, los monopolios y las corporaciones heredados del periodo colonial, las dos tendencias diferían en qué tan inmediata y qué tan radicalmente deberían atacarse estos intereses particulares. También diferían acerca de la "cuestión social", como extensión de la cual la reforma liberal debería dirigirse hacia las necesidades e intereses de las masas. Por último, estaban en desacuerdo acerca de las implicaciones de la reforma agraria para el campesinado indígena, la que los puros contemplaban como un acceso más igualitario de los campesinos a la tierra comunal. ${ }^{22}$

20 Los dos últimos párrafos son un resumen más o menos común de la política de mediados del siglo XIX, basada especialmente en la información que se encuentra en Bazant, A concise history. . . op. cit.; para un estudio más detallado de los cambios políticos del periodo, véase Richard N. Sinkin, The mexican reform, 1855-1876; a study in nation-building, The University of Texas Press, Austin, 1979.

21 Para más detalles acerca de la extracción social de los jefes liberales, véase Sinkin, op. cit., pp. 181-184; Jacqueline Covo, Las ideas de la refoma en México (1855-1861), UNAM, México, 1983, pp. 617-624.

22 El mejor tratamiento de las diferencias acerca de la "cuestión social" y de la interpretación de la reforma agraria está en: Jesús Reyes Heroles, El liberalismo mexicano, vol. 2: La sociedad fluctuante, UNAM-Facultad de Derecho, México, 1958, y vol. 3: La integración de las ideas, UNAM-Facultad de Derecho, México, 1961; Covo, op. cit.; sobre las diferencias entre puros y moderados, véanse: Bazant, $A$ concise history. . .; op. cit.; Walter V. Scholes, Política mexicana durante el régimen de Juárez, 
Estas diferencias sobre la estrategia tendían a convertirse en una brecha generacional entre los intelectuales urbanos, la mayoría jóvenes profesionistas, y los viejos militares o caudillos con una larga historia de implicación en los conflictos de la época. La cuestión principal aquí tiene que ver con la relación de los diversos bloques semiautónomos de poder y el Estado nacional. Para la joven generación, la causa principal de la anarquía política en México era la regionalización del poder, y la única solución, la diferenciación y consolidación del Estado central. Según Richard Sinkin, esto significó la sustitución del "imperio de los hombres" por el "imperio de la ley" - la transición de un proceso de negociación personalista, basado en los caudillos, a una relación institucionalizada entre estructuras de Estado-. Los viejos militares, por otra parte, pensaban en términos regionales y de patrón-cliente; después de todo, ésta era la clase de política en la que habían crecido. ${ }^{23}$

Por tal razón, con frecuencia las divisiones se reforzaban mutuamente. Los liberales radicales se encontraban entre los abogados jóvenes sin empleo, mientras que varios de los moderados prominentes eran terratenientes importantes. También estaban los más jóvenes, liberales menos prósperos, que favorecían un acercamiento más radical para reorganizar el Estado, mientras que los terratenientes y los militares eran más cautelosos y protectores de los distritos electorales existentes. Tal conjunción de características no era rasgo seguro, como es claro en los casos de Juan Álvarez, un liberal radical que también era terrateniente y militar, y José María Lafragua, un famoso abogado moderado de familia pobre. En última instancia, las posibles contradicciones y diferencias eran complejas y encubiertas, y se resolvían en el proceso de lucha y de formación de alianzas. ${ }^{24}$

La generación más joven de políticos liberales dominó el Congreso que entre 1856-57 redactó la nueva Constitución liberal que propiciaría que el país fuera a la guerra civil. Sinkin mostró que los delegados compartían antecedentes sociales homogéneos y la creencia común en la importancia de las libertades individuales y el laissez faire; pero fueron confusos acerca de cómo crear una versión estable e institucionalizada del nuevo México que imaginaban. ${ }^{25}$ Desde la posición de los delegados no era suficiente redactar una constitución cuyas leyes, en abstracto, transformarían la organización de la sociedad; también era necesario para el aparato estatal desarrollar suficiente poder y autonomía para asegurar la estabilidad y reproducción de esa nueva sociedad.

Como luego se vio, era en esto donde se encontraba la mayor contradicción del movimiento de reforma liberal. Por un lado, los liberales deseaban transformar el Estado y la sociedad civil para encuadrar su visión de una sociedad "libre", moderna, cada vez más capitalista; por el otro, para lograr tal fin no deseaban sacrificar la

1855-1872, Fondo de Cultura Económica, México, 1972; Fernando Díaz Díaz, Caudi Ilos y caciques, El Colegio de México, México, 19/2; Carmen Blázquez, Miguel Lerdo de Tejada. Un liberal veracruzano en la política nacional, E] Colegio de México, México, 1978. Acerca del tema específico de la reforma agraria, vease F. Díaz Díaz, op. cit., pp. 299-300.

23 Sinkin, op. cit.

24 Sinkin, "The Mexican Constitutional Congress, 1856-1857: A statistical analysis", Hispanic American Historical Review, vol. 53, núm. 1, 1973, pp. 1-26.

${ }^{25}$ Ibid. pp. 3, 9, 12-13. 
estabilidad o la ley y el orden, arriesgarse a lo que ellos llamaban una guerra de castas o racial generalizada y la conflagración social, y en el México de mediados del siglo xix era imposible obtener de forma completa lo primero sin arriesgarse a lo último, puesto que todo gran movimiento de reforma sólo podía tener éxito con el apoyo campesino. Como veremos, esto resultó ser el mayor obstáculo para los liberales.

Entre 1855 y 1858 , lo único en que todos los liberales -moderados y radicales, jóvenes y viejos, intelectuales y caudillos- estuvieron de acuerdo, fue en que el propósito de la revolución de Ayutla era llevar a cabo un programa de reforma sin orillar el país a la revolución social; en lo que estaban en desacuerdo las distintas fácciones era en la forma de llevarlo a cabo. Las luchas entre las diferentes posiciones tendían a poner a cada una en diversas secciones del Estado y en diferentes regiones del país, así que las fricciones existentes entre las instituciones del Estado o entre los bloques regionales de poder fueron exacerbados aún más por los conflictos dentro del partido liberal.

Tales conflictos se manifestaron con más claridad en las tres áreas del Estado entre 1855 y 1858: el Congreso Constituyente, el ejecutivo y la milicia. En el Congreso los intelectuales modernizadores trataron de restar poder al ejecutivo con el fin de institucionalizar el control del Congreso y reforzar el imperio de la ley como estipulaba la Constitución de 1857; también trataron de recortar el poder de los caudillos eliminando una serie de propuestas para la reorganización territorial presentadas por los hombres fuertes regionales. El ejecutivo, por su parte, luchó contra el Congreso para mantener sus prerrogativas con el fin de tener poder de decisión en los diversos desafíos regionales que surgieron durante esos años contra el programa liberal. ${ }^{26}$ Por último, puros y moderados lucharon en la tres estructuras: acerca de la interpretación de la doctrina liberal que debería ser atesorada en la Constitución, acerca de la mezcla radical y moderada que debería ocupar los puestos del gabinete, acerca de los grupos regionales que existían en el ejército. ${ }^{27}$

Así estaba el Estado mexicano en 1856, cuando la banda de 30 hombres cayó sobre las háciendas de Chiconcuac, Dolores y San Vicente. Su estructura y diferenciación son todavía rudimentarias. Un ejecutivo fuerte pero inestable luchaba contra los bloques regionales de poder y contra la nueva generación de intelectuales reformistas incorporados a la rama legislativa. Bajo tales circunstancias cualquier crisis, aun la más insignificante, podía hacer la diferencia entre el éxito y el fracaso para los actores involucrados; y como ya hemos visto, la confrontación que se puso en movimiento con la incursión de 1856, era todo menos insignificante.

\section{Los españoles y el Estado español}

Una explicación importante por la cual el incidente de $\mathbf{1 8 5 6}$ alcanzó tales proporciones es que era el último de una larga serie de dificultades entre México y la ex madre patria. La independencia de México,

${ }^{26}$ Ibid., pp. 8-9.

${ }^{27}$ F. Díaz Díaz, op. cit., pp. 279-295; Blázquez, op. cit., pp. 71-120; Scholes, op. cit., pp. 19-49; Bazant, $A$ concise history, op. cit,, pp. 62-76. 
iniciada en 1810 como un movimiento popular cuyo lema era "IViva la Virgen de Guadalupe y mueran los gachupines!", ${ }^{28}$ tue tan sólo el comienzo de las tensiones entre ambos países. A lo largo de la década de 1820, las facciones políticas que se disputaban el derecho a definir el proceso de formación del Estado y de la nación del recién independizado México formaron sus grupos de oposición, entre otros asuntos, respecto a qué hacer con los españoles residentes en México, y muy especialmente con aquellos que estaban en puestos burocráticos o eclesiásticos. Puesto sobre el telón de fondo del endémico sentimiento popular antiespañol, que explotó en varios puntos en el occidente y el centro-sur del país en forma de acciones de guerrilla contra ciudadanos españoles, el debate político acerca de la posición de los españoles culminó, entre agosto y octubre de 1827 , con la primera ley que formalmente expulsaba a los españoles del territorio mexicano. ${ }^{29}$

Las tensiones entre los dos países no menguaron por el hecho de que en julio de 1829 una invasión tipo bahía de Cochinos, comandada por emigrados españoles y con la aprobación tácita de la corona española, desembarcó en Tampico, en la costa noreste de México. A pesar de haber sido rechazada, esta invasión -y los rumores subsecuentes de que habría otras que nunca se realizaron- fue parte importante del contexto en el cual las facciones políticas mexicanas se disputaron el control del Estado mexicano entre 1829 y 1833. En enero de 1833, el presidente provisional Gómez Pedraza decretó la aplicación de la ley federal de expulsión contra los españoles, que había sido aprobada en $1829 .^{30}$

No obstante, el gobierno que subió al poder dos meses más tarde no obedeció el decreto de Gómez Pedraza. Las relaciones entre los dos países volvieron a tener una incómoda tregua. Entre 1836 y 1837 España reconoció la independencia de México y firmó un tratado de paz y de amistad, pero esto no puso fin a las tensiones. Fue hasta 1853 cuando los dos gobiernos estuvieron de acuerdo en cómo asentar las reclamaciones de los ciudadanos españoles que databan de los tiempos de la guerra de Independencia; en julio de 1856 los buques de guerra españoles estaban de nuevo en aguas mexicanas con la amenaza de abandonarlas sólo después de que el gobierno mexicano consintiera en levantar el embargo que pesaba sobre las propiedades de algunos de los residentes españoles. ${ }^{31}$

Junto con las inevitables tensiones diplomáticas, y aumentando las existentes entre la agonizante potencia colonial y una de sus ex colonias, estaba el hecho de que los ciudadanos españoles se habían involucrado profundamente en la economía y la política mexicanas desde la independencia; aunque las estimaciones más confiables dicen que el número total de varones españoles al final de la década de 1820 era de 6610 , su influencia era más grande que su número, ya que se hallaban concentrados regional y profesionalmente en sectores estratégicos de la sociedad mexicana. Por consiguiente, aquellos de quienes se conocía su ocupación en 1827 (un poco menos de la

28 Hugh Hamill, The Hidalgo revolt: prelude to mexican independence, University of Florida Press, Gainesville, 1966.

${ }^{29}$ Sims, op. cit., pp. 20, 87-116.

30 Flores Caballero, op. cit., pp. 158-162, 165-173.

31 Ibid., p. 173; Crónica Oficial, 25 de diciembre de 1857, p. 3; 26 de diciembre de 1857, p. 3 . 
ni itad del total de los registrados en el país), cerca de $60 \%$ eran miembris del clero, comerciantes, propietarios de minas y terratenientes; de los registrados en el país, sin embargo, cerca de un tercio estaba distribuido en el Distrito Federal y en los estados de México y Puebla. ${ }^{32}$ Una comunidad extranjera tan prominente en lo económico y lo social, estratégicamente colocada cerca de los centros de poder, estaba forzada a tener una presencia política importante, aun cuando no hubiera pertenecido a la ex metrópoli.

Pero en México los españoles fueron más lejos: se comprometieron directamente en las luchas políticas de la época. Como dijo el general Santos Degollado, con respecto a un incidente ocurrido en 1860 en el cual otros españoles fueron muertos en el distrito de Cuernavaca por guardias armados en favor de los conservadores, no era razonable esperar que la propiedad española pudiera ser protegida si los ciudadanos españoles no permanecían neutrales. Degollado estaba de acuerdo en:

castigar la grave imprudencia con la cual. . . los súbditos españoles se comportaban por toda la república, apoyando ideas retrógradas de la manera que podian y combatiendo la causa constitucional en la prensa con sus dineros y personas. Los dirigentes reaccionarios que son más crueles en la presente batalla son españoles, y los que no desean tomar las armas exasperan [a los ciudadanos] con su despotismo en las haciendas y el comercio. ${ }^{33}$

Parecía entonces que los cónsules eșpañoles que protestaban por los ataques contra los inocentes y neutrales ciudadanos españoles, lo hacían en exceso; en el México de mediados del siglo xIx, sobre el asunto de la inocencia y la neutralidad, los españoles eran culpables hasta que no probaran lo contrario. Incluso el cónsul francés comentó en seguida, al día siguiente de los asesinatos en la hacienda de San Vicente, que ya era tiempo de que las relaciones entre España y México se regularizaran, que el gobierno mexicano garantizara la seguridad de las propiedades de españoles contra las incursiones de los indios, y que "la corte en Madrid tomara severas medidas contra aquellos españoles que, ignorando los principios más elementales de la ley pública, interviniesen directa o indirectamente en todas las revoluciones internas de México". ${ }^{34}$

Se podría argumentar que, más tarde o más temprano, alguna clase de incidente entre el gobierno liberal y los españoles residentes en México habría de ocurrir. Los españoles, al involucrarse en la política conservadora, habían de hecho dado lugar a la provocación. El Estado mexicano estaba en crisis y no podía proteger a los extranjeros; tampoco los liberales estaban muy entusiasmados en dar protección a una comunidad que financiaba, defendía y a veces dirigía a sus enemigos. ${ }^{35}$ Pero nada de esto explica la forma especial que tomó

32 Sims, op. cit., pp. 31-36.

33 ACDN (Archivo de Cancelados de la Defensa Nacional, México), xI/III/2-407: Expediente de Francisco Leyva, "Oficio del General Santos Degollado al ministro de Guerra, sobre los sucesos de abril de 1860", f. 44.

34 L. Díaz, op. cit., p. 379.

35 Esto es especialmente claro en la correspondencia intercambiada entre algunas autoridades del gobierno" liberal en 1860, acerca de otro incidente en el que hubo asesinatos de españoles y que ocurrió en Morelos mientras la brigada de Leyva, parte de las fuerzas de Alvarez, hizo una revisión de rutina del área. Véase $A C D N, X I / I I I / 2-405$ : Expediente de Francisco Leyva, passim. 
el incidente, ni el hecho de que tuvo lugar en Morelos. Con el fin de entenderlo, es necesario observar de cerca la situación del campo en Morelos inmediatamente antes y después de la revolución de Ayutla.

\section{El campesinado de Morelos y los antecedentes del conflicto social}

Desde el periodo colonial, los distritos de Morelos y Cuernavaca - lo que hoy es el estado de Morelos - habían sido el asiento de una intensa agricultura comercial, dirigida en especial al mercado de la ciudad de México. La producción estaba muy diversificada e involucraba a las haciendas y a las comunidades. Ya para el siglo XVIII estas últimas estaban diferenciadas internamente, con una población mestiza grande y con importantes variaciones sociales, económicas y culturales dentro de su ámbito. Sus habitantes tendían a especializarse en los cultivos básicos de invierno que se vendían en la ciudad de México cuando otros víveres se habían agotado. Las propiedades más grandes, por su parte, también producían una gran variedad de cosechas; pero desde la década de 1750 el resurgimiento de la producción de la caña de azúcar tendía a dominar por completo la economía de las haciendas. ${ }^{36}$

De hecho en la década de 1780 la expansión del cultivo de la caña se convirtió en una importante fuente de conflicto entre las haciendas y las comunidades en Morelos. Conforme aumentaron las oportunidades de invertir, un nuevo grupo de comerciantes y funcionarios recién llegados al área compraron su parte a los terratenientes mejor establecidos, pero endeudados, e instituyeron un proceso de modernización y transformación de la industria del azúcar. ${ }^{37}$ Estos nuevos hacendados estaban interesados en asegurarse dotaciones adicionales de agua, tierra y mano de obra para abaratar la creciente producción de azúcar. Unido al aumento de la población, las crecientes necesidades de las grandes propiedades fijaron el escenario para la confrontación de campesinos y terratenientes. Las comunidades indígenas luchaban por limitar las invasiones de las grandes propiedades a su territorio, luchaban por sus derechos ancestrales al agua y se resistían a trabajar en las haciendas. Cuando menos en ciertas partes de la región, al final del periodo colonial, algunas poblaciones luchaban simplemente por su existencia; lo más amargo del conflicto parece que produjo en las comunidades un elevado y poco común nivel de solidaridad cultural y política, no obstante las diferencias económicas y sociales. ${ }^{38}$

A pesar de que no tenemos un estudio detallado del movimiento de independencia en Morelos, parece que las intensas confrontaciones que ocurrían en la región, en las décadas inmediatamente ante-

36 Sobre la economía de la hacienda y de los pueblos del periodo colonial tardío en Morelos, véase: Cheryl English Martin, "Haciendas and villages in late colonial Morelos", Hispanic American Historical Review, vol. 62, núm. 3, 1982, pp. 407-427; y Rural society in colonial Morelos. University of New Mexico Press, Albuquerque, 1985; Horacio Crespo (comp.), Morelos: cinco siglos de historia regional, Centro de Estudios Históricos del Agrarismo en México/Universidad Autónoma del Estado de Morelos, México y Cuernavaca, 1985, pp. 81-127.

37 Martin, "Haciendas. . .", op. cit., pp. 408-412; y Rural society. . ., op. cit., pp. 97-120.

${ }^{38}$ Ibid., "Haciendas. . ", op. cit., pp. 412-423; y Rural society. ., op. cit., pp. 155-192. 
riores a la guerra de Independencia, generaron cierto apoyo para el movimiento en las poblaciones del área, especialmente para la rama reformista representada por los caudillos insurgentes José María Morelos, Vicente Guerrero y Juan Álvarez. ${ }^{39}$ Como John Tutino ha expuesto recientemente, el apoyo del que gozaba Morelos en esta región no era suficiente para asegurar su victoria sobre los realistas; ${ }^{40}$ al mismo tiempo, el compromiso conservador al que se llegó en 1821 no satisfizo a nadie. Durante las primeras dos o tres décadas después de 1821, un acopio subyacente de efervescencia social amenazó con explotar al menor signo de conflicto o disturbio político. Los caudillos radicales de la región compuesta por los estados de Morelos y Guerrero, donde se concentraba gran parte del apoyo para Morelos, Guerrero y Álvarez, eran acusados por los terratenientes locales y los políticos de la nación de tratar de fomentar una repetición de los sucesos de 1810 o, lo que era peor, el principio de una guerra de castas. ${ }^{41}$

Pero hasta la década de 1840, cuando el descenso de la economía que golpeó a las haciendas como resultado de la destrucción causada por la guerra de Independencia, combinado con las dificultades financieras que enfrentaron muchos de los nuevos hacendados - debido a los préstamos que habían otorgado a los realistas-, impidió que las grandes propiedades realizaran nuevas invasiones a las tierras comunales y objetaran sus derechos al agua. A estos problemas se añadieron las campañas antiespañolas de finales de la década de 1820 y principios de la de 1830 , que afectaron a una significativa proporción de la elite de terratenientes de la región. Al menos económicamente, esto significó quizá un aumento en la autonomía y autosuficiencia de las poblaciones en las décadas inmediatas a la independencia, y fueron los campesinos quienes pudieron rentar tierras de las haciendas. ${ }^{42}$

No obstante, para la década de 1840 muchos hacendados dedicados al azúcar en Morelos estaban otra vez al borde de la ruina, y a su vez fueron reemplazados por otro nuevo grupo de comerciantes y financieros. Como en el caso de 1780 , el nuevo grupo de terratenientes comenzó a invertir, a transformar tecnológicamente y a expandir las haciendas azucareras. ${ }^{43}$ Para las comunidades indígenas significó la vuelta a las condiciones de las ofensivas previas; lo que lo hizo peor fue que, al menos por unas cuantas décadas, las condiciones habían estado mejorando. Por lo tanto, aun cuando el acceso a la tierra y los derechos al agua de los pueblos podían ser objetivamente mayores que antes de la independencia, las acciones agresivas de los nuevos hacendados eran inaceptables, en particular, porque interrumpían el

39 María Teresa Huerta, "Formación del grupo de hacendados azucareros morelenses, 1780-1840", en Crespo, op. cit., pp. 158-155; Hamnett, Roots of insurgency: mexican regions, 1750-1824, Cambridge University Press, Cambridge, 1986, pp. 142-149, 159-164.

40 Tutino, op. cit., pp. 188-191. Véase también. Hamnett, Roots, op. cit., pp. $157-165$

4 Brígida von Mentz, "La región morelense en la primera mitad del siglo xIX: Fuentes e hipótesis de trabajo", en Crespo, op. cit., pp. 136-142.

12 La posibilidad de aumento de la autonomía o autosuficiencia para los campesinos después de la independencia, está bien discutida en Tutino, op. cit., pp. 215-24l.

43 Huerta, op. cit., pp. 154-161; e "Isidoro de la Torre: El caso de un empresario azucarero, 1844-1881", en Formación y desarrollo de la burguesía en México. Siglo XIX, Ciro F.S. Cardoso (coord.) Siglo XXI Editores, México, 1978, pp. 175-181. 
aumento de la autonomía. Como antes, el escenario estaba listo para la confrontación, esta vez con un grado especialmente elevado de ultraje moral; y al final de la década, los campesinos de Morelos habían hallado poderosos aliados potenciales, tanto en los batallones locales de la guardia nacional como entre los impacientes campesinos de otras partes de "el sur". ${ }^{44}$

En un artículo reciente acerca de la sociedad rural en Morelos a fines del periodo colonial, Cheryl English Martin alega, con bastante eficacia, que en el conflicto entre las economías de la hacienda y de los pueblos en Morelos, los terratenientes tomaron la que sería la posición liberal medio siglo más tarde, arguyendo que las comunidades indígenas estaban pasadas de moda y que su categóría de corporación debería abolirse en favor de un mercado de la tierra totalmente abierto. Por supuesto, en especial en Morelos, tal mercado estaba condenado a ser dominado por la hacienda; en las poblaciones era muy correcto, desde la posición de su propia supervivencia, invocar "el modelo profundamente conservador del pueblo de indios, apoyado por todas las garantías guardadas como reliquias en la real legislación de la era anterior". ${ }^{45}$ Contrario a lo que sugiere este análisis y a lo que ha sido discutido por ciertos especialistas respecto a otras partes de México; ${ }^{46}$ tanto en la independencia como en la revolución de 1855, y en esta última de manera más importante, las comunidades campesinas militaron con los liberales. La explicación para esto debe hallarse en el análisis de las tradiciones políticas de "el sur", con más claridad, en la manera en que interactuaron con la influencia personal y militar de Juan Alvarez, caudillo liberal papulista y heredero del manto de los generales Morelos y Guerrero.

\section{Juan Ālvarez y "Los Pintos"}

Juan Álvarez y sus seguidores no inspiraban mucha confianza ni entre los conservadores ni entre los liberales; de hecho, los intelectuales, políticos y militares de ambos lados de la barrera ideológica veían el movimiento de Álvarez como compuesto de semibárbaros, apenas civilizados; con frecuencia la prensa de oposíción se refería a Álvarez mismo como "la pantera del sur". ${ }^{47}$ Algunas de las razones para esta desconfianza tenían que ver con los orígenes de Alvarez; hijo de padre español y madre mexicana, quedó huérfano a la edad de 17 años y, maltratado por su tutor, parece que fue forzado a trabajar como vaquero antes de enrolarse en las fuerzas insurgentes durante la guerra de Independencia; más todavía, sus escasos tres años de escolaridad no lo congraciaban con los intelectuales, aun los

44 Id., "Formación. . ", op. cit., p. 168; Leticia Reina, Las rebeliones campesinas en México (1819-1906), Siglo XXI Editores, México, 1980, pp. 85-120, 157-182. Las alianzas potenciales de campesinos entre sí y de campesinos y guardias nacionales están tratadas con detalle más adelante. Durante el siglo XIx, "el sur" era el nombre dado a la región que se extiende desde el sur de la ciudad de México, y abarca los estados de Guerrero, Morelos, Puebla y Tlaxcala.

45 Martin, "Haciendas. . ", op. cit., p. 420

46 Véanse en especial las obras de J. Meyer, Problemas. . y Esperando a Lozada, ya citadas.

${ }^{47}$ F. Díaz Díaz, op. cit., pp. 262-263. 
de su misma línea política. ${ }^{48}$ En suma, estaba leios de ser el "indio' que sus enemigos vociferaban que era; aunque huérfano, recibió una herencia de más o menos 30000 pesos (el precio de una pequeña hacienda); 49 y ya para los tiempos de la revolución de 1855 era un hombre con propiedades y rico. ${ }^{50}$

En última instancia, la hostilidad de los liberales y conservadores hacia Alvarez tenía que ver más con sus creencias políticas que con sus antecedentes sociales. Comenzando con la guerra de Independencia, pero con mayor fuerza en los treinta y los cuarenta, Álvarez apoyó por todo "el sur" de manera consistente las demandas de los campesinos indios para que se les regresaran sus tierras. Dada la regionalización. del poder en el México independiente, los caudillos que controlaban el gobierno central se vieron repetidas veces en la necesidad de pedir a Álvarez que "pacificara" las rebeliones agrarias que estallaron en varias partes del territorio bajo su influencia. Cuando se le pidió que fuera mediador en una rebelión de 1843 en el distrito de Chilapa, Guerrero, su respuesta fue acorde a su posición: sugirió que se diera amnistía total a los indios rebeldes, que el asunto de la tierra fuera resuelto en la región enviando a un mediador imparcial para que examinara los títulos de propiedad de ambos lados y que tanto campesinos como terratenientes estuviesen obligados a aceptar los resultados de la mediación. No es sorprendente que sus sugerencias no se aceptaran. ${ }^{51}$

En los últimos años de la década de 1840 Alvarez había adquirido una gran reputación entre los indios y campesinos del sur y del centro de México, algunos de los cuales se referían a él como "el tata Juan". ${ }^{52}$ Su entusiasta resistencia a la invasión norteamericana, que al fin lo obligó a retirarse hacia el sur y continuar luchando con una fuerza compuesta de voluntarios de los pueblos del área, acrecentó su reputación; además de ser sincero su apoyo al campesinado —con seguridad mucho más de lo que algunos historiadores le acreditanera capaz de traducir el apoyo que le daban en una política regional de bases sólidas. ${ }^{53}$

Como mostró la exitosa propuesta de Alvarez para la creación del nuevo estado de Guerr ‘ro en 1848-50, una política regional con bases sólidas podía teóricamente ser negociada por poder en el ámbito nacional. ${ }^{54}$ En esto quizá, lo mismo que en su propia jerarquía como poderoso terrateniente, descansa en realidad la profunda contradicción del populismo de Álvarez. Por una parte venía de una larga línea de combativos caudillos populistas, hombres cuyas creerıcias y tradiciones los habían comprometido profundamente con una visión del futuro de México que incluía un verdadero igualitarismo liberal, un jacobinismo estilo México; siguiendo esta línea, Alvarez no podía sino apoyar las justas demandas de los campesinos, cuyas tierras

48 Daniel Muñoz y Pérez, El general Juan Alvarez: ensayo biográfico y selección de documentos, Editorial Academia Literaria, México, 1959, p. 3 (Col. Reforma e Imperio, 2).

49 Ibid.

${ }^{50}$ F. Díaz Díaz, op. cit., pp. 302-303, 331.

${ }^{51}$ L. Reina, op. cit., pp. 85-91, especialmente para el caso de Chilapa; véase también F. Díaz Díaz, op. cit., pp. 328-331.

${ }^{52}$ F. Díaz Díaz, op. cit., pp. 223-226.

53 Ibid., pp. 219-231; L. Reina, op. cit., pp. 157-161.

${ }^{54}$ F. Díaz Díaz, op. cit., Pp. 219-231. 
habían sido usurpadas por los poderosos hacendados. Pero por otra parte, como miembro de la clase terrateniente, como caudillo militar, como contendiente por el poder nacional cuya influencia y prestigio descansaba en buena parte en su habilidad para manejar su numerosa clientela, Álvarez no podía permitir que el contenido social del movimiento rural que él alentaba y cuya dirección pregonaba se le fuerà de las manos. Como veremos, todas estas tendencias contradictorias estaban actuando en Morelos entre 1848 y 1856; para culminar de modo dramático, comenzaron y terminaron en la hacienda de Chiconcuac.

En febrero y marzo de 1848, mientras la ciudad de México era ocupada por las tropas de Estados Unidos, los pobladores de la parte occidental del distrito de Cuernavaca iniciaron una ofensiva contra las haciendas de la región. Declarando que actuaban con la autoridad de Álvarez, los campesinos atacaron a los ciudadanos ricos del pueblo de San. Francisco Chicolula el 29 de febrero, mientras otro grupo destruía al mismo tiempo los mojones de la hacienda de Miacatlán. Entonces, en varios lugares durante el mes de marzo, el teniente coronel José Manuel Areliano, oficial de la guardia nacional bajo las órdenes de Álvarez, condujo fuerzas combinadas de campesinos y soldados en una serie de acciones contra las haciendas del valle de Cuernavaca, modificando las líneas divisorias para reflejar mejor las reclamaciones comunales. Comenzó en las haciendas de Chiconcuac y San Vicente, colocando los mojones en el patio de la casa del dueño. ${ }^{55}$

Debido a que el país estaba ocupado por tropas extranjeras, el general Alvarez no estaba muy conforme. Escribió al comandante a cargo del Estado de México (al que pertenecía el oeste de Morelos en ese tiempo), disociándose de la conducta de Arellano y urgiéndolo para que castigara a éste y a todos los otros participantes en el movimiento; ${ }^{56}$ pero reservó una respuesta más categórica para Arellano, a quien castigaba por no dar prioridad a la emergencia nacional; escribió: "Cuando en Tetecala lo hice a usted comandante de ese batallón, no le ordené que lo usara para involucrarse en las trifulcas de otros". Según continuaba Alvarez en su carta, la idea era defender la nación contra el invasor. Álvarez se rehusó expresamente a hacer declaraciones acerca de la justicia de las reclamaciones de los indios; en vez de eso señaló que, al apoyar a los campesinos contra los terrratenientes, Arellano había forzado a éstos a buscar la protección de los invasores. Esto era inexcusable dadas las circunstancias, cuando era una inconsciencia que los mexicanos se enfrentaran unos a otros. ${ }^{57}$

Los hacendados del distrito de Cuernavaca parecían, sin embargo, tener menos escrúpulos que Álvarez acerca de la confrontación con otros mexicanos. En su reporte acerca de los incidentes, escrito a mediados de marzo, Lucas Alamán informa desde la ciudad de México que las invasiones habían sido detenidas por personal de la hacienda en unión de comandos norteamericanos acampados en Cuernavaca. Y concluía: "Pero cuando el ejército norteamericano se retire, temo que este tipo de revuelta se repetirá y nos dejará en un

ss L. Reina, op. cit., pp. 157-159.

56 Ibid., p. 161; F. Díaz Díaz, op. cit., p. 223.

57 El documento original aparece reproducido en $L$. Reina, op. cit., p. 161. 
estado de gran inseguridad." 58 Esto fue un ejemplo de la clase de mentalidad que llevó a muchos de los terratenientes de la región a apoyar la intervención francesa en la década de $1860 .{ }^{59}$

Ya sea bajo la influencia del comandante norteamericano o la de Juan Álvarez, el apoyo de la guardia nacional a las invasiones de las haciendas parece haber cesado después de marzo de 1848, llevando este movimiento rural particular a su fin; aunque no fue el término de la efervescencia en Morelos. Un año más tarde, desde Cuernavaca hasta Jantetelco, al este de Morelos, se extendieron los rumores de que los indios planeaban una rebelión contra los extranjeros y otros propietarios; mientras no pudieran ser confirmados, los rumores sólo sirvieron para aumentar las tensiones en el área, como quedó dramáticamente claro en la confrontación que sobrevino entre el gobernador del Estado de México y los terratenientes locales. Cuando el gobernador sugirió, en julio de 1849, que los hacendados debían evitar la guerra de castas mejorando las condiciones de los peones y no invadiendo las tierras de los pueblos, los terratenientes respondieron castigando al estado por su falta de apoyo y armándose contra lo que ellos oscuramente predecían como el fin de la civilización. ${ }^{60}$

Las cosas sólo empeoraron los años siguientes, en especial con el resultado - muy fuerte para los terratenientes y las autoridades- de la guerra de castas en Yucatán. En julio de 1852 una de las autoridades del pueblo de Xochitepec, que colindaba con la hacienda de Chiconcuac, reportó que una potencial guerra de castas con fines de expropiación se había estado fraguando durante tres años. Los españoles de la localidad, decía, en particular un tal Francisco Herrera, sólo fomentaba la inquietud con sus frecuentes borracheras y abusos contra la población, durante las cuales no respetaba la autoridad, ya fuera del patriarca en su propio hogar o de la investidura pública en la persona del alcalde. Dado el "socialismo" que había golpeado a Yucatán, concluía, tenía temor de una guerra de castas similar en su distrito. ${ }^{61}$

La más fuerte manifestación de las tensiones subyacentes en el distrito de Morelos se dio, sin embargo, en octubre de 1850. El día 17 los barrios de indios de la ciudad de Cuautla invadieron la hacienda de Santa Inés. Once poblaciones del área de Puente de Ixtla también se hallaban implicadas, pero en apariencia habían cesado su participación. Cuando el comandante del lugar trató de ordenar a la guardia nacional que reprimiera la rebelión, los hombres se rehusaron. No se trataba de un caso de intranquilidad (intranquilidad pública), respondieron los soldados, sino que

58 Citado por F. Díaz Díaz, op. cit., p. 223.

59 Este juicio está basado en una serıe de documentos que se encuentran en el AGN (Archivo General de la Nación, México), en los ramos de Gobernación y Segundo Imperio, y demuestran las cordiales relaciones que existían entre algunos hacendados y el emperador Maximiliano. Véase por ejemplo, AGN, Gobernación, leg. 1161(2), exp. 18, 1865: "Oficio del Ministerio de Gobernación al Ministerio de Hacienda", 9 de febrero, que explica que el hacendado Felipe Neri del Barrio prestó dinero al gobierno imperial.

60 Acerca de los rumores de rebelión en el este de Morelos, véase AHDN, $\mathrm{x}] / 481.3 / 3060$. Sobre el incidente con el gobernador del Estado de México, véase Moisés González Navarro, Anatomía del poder en México, 1848-1853, El Colegio de México, México, 1977, pp. 161-165.

61 AHDN, XI/481.3/3268, "Oficio de la autoridad local de Xochitepec", 12 de junio de 1852, ff. 5-6. 
la gente, exasperada por no tener dónde vivir y convencida de que sus tierras habían sido usurpadas por largo tiempo por los hacendados, había enviado sus quejas al gobierno desde hacía un año, pero en vez de escuchar estas quejas, el gobierno las olvidó y el que era prefecto en ese entonces arrestó a varios de los que habían firmado la petición y solicitó que se les sometiera a prueba; así se hizo pero no se encontró ningún crimen, y que hoy, como consecuencia de esta ofensa y no teniendo recursos suficientes para seguir un pleito por el asunto de sus tierras en las cortes, la gente había decidido actuar, persuadida de que toda la gente tiene el derecho a rebelarse cuando la ley no es efectiva y las autoridades no escuchan. (Las cursivas son mías.)

Entonces, según concluían los soldados, no había habido crimen, y por lo tanto era imposible tomar las armas "contra [nuestros] hermanos y contra [nuestros] derechos, porque todos [nosotros] pertenecemos a la clase popular, pero protestamos obedecer la autoridad siempre y cuando sea necesario reprimir el verdadero desorden". (Las cursivas son mías.)

El movimiento fue por último reprimido por guardias rurales de las haciendas combinadas con tropas traídas de otras partes del Estado de México. Con el cabildo mediando entre ellos y los terratenientes, los rebeldes estuvieron de acuerdo en formar una comisión para negociar la tierra en cuestión. Mientras tanto el gobierno decidió recoger las armas que existían en el distrito con el fin de prevenir estallidos futuros. Dado el balance de fuerzas, y el alto grado de animosidad contra los hacendados, el comandante militar de la localidad decidió dejar el asunto de las armas al cabildo, obligado por las graves protestas de los terratenientes. El resultado final fue que ninguna de las dos partes mantuvo sus promesas: la situación de la tierra no fue revisada, y la inquietud continuó entre la población todavía armada y con el apoyo potencial de las milicias locales del vecino estado de Guerrero. ${ }^{6}$ '

Éste era el balance de fuerzas político y social en el caso de Morelos en 1854-55, cuando estalla la revolución de Ayutla. De un lado estaba la clase dominante del lugar, compuesta principalmente por los grandes hacendados del azúcar y con una importante fachada de comerciantes españoles. En la década de 1840, algunos de los nuevos allegados a sus filas eran parte del creciente y poderoso grupo nacional de agiotistas que prestaban dinero al gobierno central. ${ }^{63}$ Apenas nos sorprende que demandaran, y normalmente consiguieran, el apoyo ilimitado del gobierno central para mantener a los campesinos bajo control mientras expandían la producción de azúcar.

Del otro lado, el campesinado de Morelos, aunque internamente diverso y diferenciado, se mantenía unido en su resistencia a la pérdida de la tierra y de los derechos al agua, y usaba cada oportunidad para luchar por la restauración de su base de subsistencia expandida después de la independencia. En esta lucha, los campesinos de los distritos de Cuernavaca y Morelos encontraron aliados poderosos en

62 AHDN, XI/481.3/3119, "Oficio del subprefecto de Morelos al prefecto del distrito", Morelos, 17 de octubre de 1850, ff. 24-25. La cita textual está en el f. 24. Véase también L. Reina,.op. cit., pp. 162-163.

63 Tanto Bárbara Tenenbaum (The political penury: debts and taxes in Mexico, 1821-1856, University of New Mexico Press, Albuquerque, 1986) como María Teresa Huerta (Formación. .., op. cit.) demuestran el traslape entre el grupo de agiotistas con la nueva generación de terratenientes en Morelos a mediados del siglo XIX. 
Juan Alvarez y los batallones de la guardia nacional que él había organizado en todo "el sur"; aunque Álvarez mismo, como terrateniente y político nacional en potencia, paró en seco las invasiones violentas de tierra en la región. Como ya hemos visto, estas líneas de batalla ya estaban dibujadas en los años de la guerra mexicano-norteamericana, pero se habrían de volver más nítidas y violentas a mediados de la década de 1850 .

\section{Morelos y la revolución de Ayutla, 1854-56}

Para diciembre de 1854 las fuerzas de Âlvarez habían comenzado su ofensiva desde Guerrero, a través de Morelos, hacia la ciudad de México. Atravesando los distritos de Morelos y Cuernavaca, las fuerzas de la guerrilla, aparentemente bajo lás órdenes de Âlvarez, comenzaron a ocupar los pueblos y las ciudades, incluyendo Cuautla, Jonacatepec, Tlaquiltenango, Jojutla y Tetecala. En Jojutla, Tlaquiltenango y las haciendas cercanas las bandas robaban y saqueaban, forzando a los jueces de paz de estos lugares a subscribir documentos en apoyo del movimiento de Álvarez. Las autoridades del distrito de Cuernavaca también reportaron que los rebeldes se habian reunido en las haciendas de Temisco y San Vicente y que ellos predecían que tal cosa presagiaba el inicio de una campaña para exterminar a los blancos, planeada en el área desde hacía tiempo. ${ }^{64}$

Es dudoso que el propósito del movimiento local fuera la exterminación de la raza blanca, sobre todo porque muchos de sus jefes eran blancos; pero las temerosas autoridades estaban en lo correcto al señalar a las bandas organizadas de la guerrilla local. Los grupos de rebeldes de la localidad que apoyaban a Álvarez parecían tener profundas raíces en las poblaciones del área; estaban dirigidos por lugareños, conocían bien el terreno y podían contar con el apoyo de la población civil que los escondía y les suministraba provisiones. Esto fue muy claro para los oficiales militares enviados a reprimir la rebelión. Como reportó el general Francisco Guitián desde Jojutla en enero de 1855, él era por completo incapaz de enfrentar a los rebeldes: éstos simplemente no ofrecían resistencia y se retiraban a su escondite en el rancho de Los Hornos; su jefe, Manuel Casales, era de allí, según explicaba Guitián. ${ }^{65}$ En verdad, ninguna fuerza militar de fuera del área podía competir con esta clase de conocimiento de los lugareños que los guerrilleros explotaron hasta la saciedad para realizar una guerra psicológica de rumores contra las tropas regulares que los perseguían de pueblo en pueblo y de hacienda en hacienda, pero que nunca podían ver al enemigo cara a cara. ${ }^{66}$

Más adelante, dos uncidentes ilustran la dimensión del apoyo a Alvarez y de la revolución liberal en el distrito de Morelos. El primero, en Cuautla, fue un levantamiento urbano dirigido por un zapatero. La noche del 16 de diciembre de 1854 , varios grupos de 20 a 30 hombres tomaron la ciudad moviéndose en los alrededores y en

64 AHDN, XI/481.3/505l, cartas varias, 22 de diciembre de $1854-3$ de enero de 1855, ff. 11-12, 16-17v, 19-19v, 21-21v, 23-24, 28-29, 145, 157-158v; AHDN, XI/481.3/5052, "Parte del encargado de la Comandancia Militar de Cuernavaca, Juan Estrada, al Ministerio de Guerra", Cuernavaca, 15 de diciembre de 1854, ff. 1-2.

${ }^{65}$ AHDN, XI/481.3/5051, "Parte del general Francisco Guitián al Ministerio de Guera y Marina", Jojutla, 10 de enero de 1855, ff. 68-69.

66 Ibid., f, 68 . 
las poblaciones y haciendas vecinas en un intento de acumular recursos y provisiones. Una fuerza combinada de más de 200 hombres fue en principio incapaz de reprimir la rebelión y llevó al ministro de Guerra a sospechar la complicidad de las autoridades locales, incluyendo al comandante militar. El comandante general de Cuernavaca, enviado a Cuautla a restaurar el orden, recibió instrucciones de cobrar una multa de 3000 pesos a la población y de castigar a los ciudadanos, incluyendo a los terratenientes que permanecieron neutrales y no ayudaron a las fuerzas del gobierno. ${ }^{67}$

Otro centro de apoyo a Álvarez y a la revolución liberal fue el pueblo de Tepalcingo, en la parte este del territorio cercano a Guerrero. En enero de 1855 el general Nicolás de la Portilla fue llamado al pueblo a causa de los reportes de ataques de "bandidos". Para cuando él llegó, se encontró con evidencias de un incidente de proporciones mayores: tanto el alcalde como el cura habían sido atacados, algunas mujeres habían sido violadas y la mayoría de los hombres de la banda responsable habia desaparecido. Portilla se las arregló para encontrar a cuatro de los atacantes escondidos en el pueblo y los mató a tiros. Algunos habitantes del lugar también estaban implicados, comunicó Portilla, pero como los había encontrado desarmados no los mató. Aparentemente el resto de la banda escapó a los cerros de Huautla, un área montañosa que separa a Morelos de Guerrero. El jefe del ataque, decía Portilla, era un "pinto suriano" - un partidiario de Âlvarez-; mientras saqueaban, los atacantes gritaban "Viva la Virgen de Guadalupe, viva Villalva, viva Alvarez!"'68

Quizá lo más interesante del reporte del general Portilla fue el suceso que él puso como antecedente; ya en marzo de 1854 una serie de casos en la región señalaban con precisión a Tepalcingo como un pueblo partidiario de la revolución del sur; en consecuencia, la población de Tepalcingo había sido desarmada y algunos de sus prominentes ciudadanos, incluyendo a Amado Popoca, habían sido arrestados. Los fusiles de la dispersa guardia nacional fueron sacados del pueblo. El ejército regular también había desarmado a la guardia nacional en otros pueblos de Morelos y provocado que el comandante militar de Jonacatepec se quejara, el 31 de marzo, de que la región había quedado sin defensa para enfrentar la próxima rebelión de los seguidores de Álvarez. ${ }^{69}$

Junto con otros incidentes ocurridos en Morelos, Cuernavaca y Guerrero, estos acontecimientos tan sólo eran la cresta de la ola del sentimiento popular en "el sur" que puso a Juan Álvarez y a su movimiento liberal a las puertas de la ciudad de México. Resulta interesante saber que la composición social del grupo que apoyaba a Álvarez era muy compleja. Aunque podía apreciarse con claridad el campesinado de los pueblos, existía un fuerte componente de las áreas urbanas y de los trabajadores de las haciendas; también aglutinaba a pequeños comerciantes, campesinos prósperos y a algunos artesanos de las ciudades. Lo que parecia unificar a sus partidiarios,

67 AHDN, XI/481.3/5052, ff. 3-4, 37-38, 45-45v, 53-53v.

68 AHDN, XI/481.3/505l, "Parte del general Nicolás de la Portilla al Ministerio de Guerra y Marina", Morelos, 15 de enero de 1855, ff. 100-101v.

69 Ibid., ff. 105-105v; "Oficio del comandante militar de Jonacatepec al comandante en jefe de la línea limítrofe del sur", Jonacatepec, 31 de marzo de 1854, ff. 124-125. 
a pesar de su diversidad, era el rechazo a la clase dominante local, ya fueran españoles o mexicanos, en especial sus prácticas de prestamistas en las ciudades y su expansionismo como terratenientes en el campo. ${ }^{70}$

Cuando se combinó con otras rebeliones rcgionales, la de "el sur" ayudó a forzar a Santa Anna para que dejara la presidencia en agosto de 1855. Para octubre, Juan Álvarez era presidente interino y había designado un gabinete dominado por los liberales radicales; ya desde el principio, los liberales más moderados se mostraban suspicaces acerca de Álvarez y las fuerzas sociales que representaba. Para mayo de ese mismo año, el prominente liberal Benito Gómez Farías había escrito a su hermano que uno tenía que ser "estúpido o malvado para apoyar una revolución encabezada por Álvarez". ${ }^{71}$ Conforme 1855 llegaba a su fin, una facción más grande del partido liberal estuvo de acuerdo con Gómez Farías.

Aunque muchos historiadores del periodo han sugerido que el gabinete de Alvarez cayó en diciembre de 1855 porque aprobó la Ley Juárez, ${ }^{72}$ una explicación más profunda debe tomar en cuenta dos factores adicionales; el primero fue el aumento de las tensiones entre las facciones de los moderados y los radicales, personificadas por Álvarez y su moderado ministro de Defensa Ignacio Comonfort; y el segundo, el iniedo que la base social de Álvarez despertaba entre todos los miembros de su propio partido. Ambos factores estaban interrelacionados; una importante fuente de tensión entre Alvarez y Comonfort, por ejemplo, era el poder del ejecutivo. Los conceptos redactados inicialmente en el Plan de Ayutla, donde la influencia de Álvarez era la más fuerte, establecían que la revolución liberal iba a ser intensamente federalista. Cuando Comonfort supervisó la reforma del plan en Acapulco, sin embargo, extendió considerablemente el potencial de centralización. Se ve con claridad que las tendencias centralistas de Comonfort eran resultado en parte de sus puntos de vista más moderados y cautos, pero su otra preocupación, compartida por puros y moderados, era que el federalismo permitiría a Alvarez incitar a sus partidarios radicales con impuñidad. ${ }^{73}$

Volviendo a la situación del Estado mexicano a mediados del siglo xix, uno de los más grandes debates entre los liberales era cómo institucionalizar y diferenciar las estructuras del Estado con el fin de obtener control y paz sociales. En el Congreso Constituyente, que representó en especial a los más jóvenes y progresistas de los liberales, evitar el caudillismo y sus grupos electorales preexistentes fue una lucha que consistió en superar la inquietud endémica y el conflicto sanguinario con el fin de centralizar el poder bajoel imperiode la ley. El punto de preocupación de los reformadores liberales era que Alvarez parecía peligroso: no sólo era un poderoso cacique regional, sino que la gente de sus distritos era precisamente del tipo que haría imposible alcanzar la paz.

70 La mayoría de los documentos acerca de Morelos en el AHDN contiene múltiples referencias a una fuerte corriente antiespañola y de animadversión contra los comerciantes y hacendados españoles.

11 F. Díaz Díaz, op. cit., pp. 279-280.

72 Véase por ejemplo Bazant, $A$ concise..., op. cit., pp. 69-70.

73 Algunas de las divisiones en potencia entre los liberales están tratadas, en lo que respecta a la figura de Álvarez, por F. Díaz Díaz, op. cit., pp. 279-282, 286-290. 286-290. 
En su anhelo por competir por el poder nacional, Alvarez había removido las viejas cuestiones de la tierra y la justicia que hubiera sido mejor dejar en paz. El hecho de que entre 1848 y 1854 el gobierno central había sido forzado a enviar tropas a Morelos en dos ocasiones con el fin de desbaratar las coaliciones de los campesinos y los batallones de la guardia nacional que luchaban por tierra y justicia, no era un buen presagio para la causa del orden ni para la clase terrateniente. Y la mayoría de los liberales mexicanos, sin importar sus opiniones acerca de los monopolios coloniales y la iglesia católica, no estaban interesados en desafiar el sistema de propiedad privada ni de arriesgarse a una guerra de castas total para poder realizar sus reformas.

Por eso, al final la tendencia populista del liberalismo mexicano -tendencia que Álvarez había heredado de José María Morelos identificaba justicia social con redistribución y con tierra, y que había echado raíces profundas en "el sur", incluyendo Morelos - era incompatible con las diferencias sociales, raciales y culturales que la sociedad mexicana había heredado del periodo colonial. No se podía, en última instáncia, tener liberalismo jacobino y paz social; y cuando llegó el impulso e hizo presión, la mayoría de los liberales mexicanos prefirieron la paz social. Esta contradicción, más que las provisiones moderadas de la Ley Juárez, fue lo que derrocó al gobierno de Âlvarez tan sólo unos cuantos meses después de que había asumido el poder; pero en diciembre y enero (1855-56), las implicaciones de esta contradicción estaban apenas comenzando a manifestarse en el plano histórico.

\section{La revolución conservadora en Puebla y la guardia nacional de Morelos}

En enero de 1856 los rebeldes conservadores ocuparon la ciudad de Puebla después de proclamar el Plan de Zacapoaxtla, en el cual impugnaban a los liberales por su posición acerca de la iglesia católica. El presidente Ignacio Comonfort, que acababa de reemplazar a Alvarez, se vio forzado a desplegar todas las fuerzas disponibles para reprimir el movimiento que en seguida se convirtió en el reto más formidable jamás enfrentado por la joven revolución liberal. A pesar de haber vuelto apenas a la vida privada en su estado natal de Guerrerq, Álvarez contestó con entusiasmo al llamado de Comonfort para defender los principios liberales. Entre los batallones que Álvarez desplegó para luchar en Puebla estaban algunos de los distritos de Morelos y Cuernavaca, los mismos a los que él había distribuido armas para llevar a cabo la revolución de Ayutla tan sólo unos meses antes. ${ }^{74}$

Al final, Comonfort fue capaz de reunir una impresionante cantidad de fuerzas contra los rebeldes conservadores, aunque a costa de una gran carga financiera para su administración. A finales de

74 Sobre la revuelta de Puebla, véase Bazant, $A$ concise. ., op. cit., p. 70; Ejército de Operaciones sobre Puebla, "Parte general", 1856; Antonio de Haro y Tamariz, "Manifiesto acompañando el plan político proclamado en Zacapoaztla el 19 de diciembre de 1855', Puebla, 23 de enero de 1856. Acerca de la participación de las fuerzas de Álvarez, véase AHDN, XI/481.3/5577: "Partes del general Nicolás de la Portilla sobre la situación en los distritos de Morelos y Cuernavaca", 23 de abril de 1856 y 7 de mayo de 1856 , ff. $7-9 \mathrm{v}, 17-18 \mathrm{v}$. 
de marzo, la rebelión había sido definitivamente sọfocada. En Morelos, sin embargo, los fuegos artificiales tan sólo comenzaron una vez que los batallones de la guardia nacional, movilizados para defender los principios liberales en el vecino estado, regresaron a reforzar los mismos principios en su territorio natal. Incluso antes de que los soldados comenzaran su viaje de regreso a casa, los terratenientes de Morelos sabían lo que significaría su presencia de nuevo. El 24 de marzo un grupo de éstos escribió personalmente a Comonfort solicitando que las fuerzas del estado de Guerrero que habían servido en Puebla regresaran a su estado sin pasar por los distritos de Morelos y Cuernavaca, y que estos distritos también fueran protegidos del regreso de sus propios soldados por un contingente reforzado de tropas nacionales bien disciplinadas. Si estas medidas no se efectuaban, hacían notar los hacendados, el área de Morelos y Cuernavaca inevitablemente caería en una guerra de castas y sufriría "la plaga del socialismo". ${ }^{75}$ En los siguientes meses, debido a que una nueva coalición de campesinos y guardias nacionales se embarcó una vez más en una lucha contra las grandes propiedades, parecía que las predicciones de los terratenientes se convertirían en realidad.

El 17 de abril de 1856, el prefecto del distrito de Morelos escribió al presidente Comonfort informándole que estaban ocurriendo graves disturbios en los pueblos bajo su mando. Según el prefecto, una combinación de trabajadores de las haciendas y criminales comunes estaba detrás de la serie de incidentes recientes, incluyendo el intento de asesinato del capitán de las fuerzas de seguridad, el paro de labores en las haciendas de Cocoyoc y Santa Inés, una demanda aparentemente generalizada en todas las propiedades de aumento de salarios y la reunión de 200 hombres en el pueblo de Tetelcingo como un rumor que preludiaba una movilización general contra las haciendas. El prefecto terminaba su carta con una petición de refuerzos que el ministro de Guerra atendió en seguida enviando el 19 de abril una brigada a Cuautla, Morelos. Para los siguientes meses, los distritos de Morelos y de Cuernavaca entraron en lo que parecía ser un estado de guerra. ${ }^{76}$

Entre el 23 de abril y el 7 de mayo, el comandante militar de Cuautla, general Nicolás de la Portilla, envió dos reportes al ministro de Guerra que resumían con claridad la situación en el campo de Morelos. Situaba el inicio de la inquietud en los meses que antecedieron al triunfo de la revolución de Ayutla. En agosto de 1855, según Portilla, Álvarez había distribuido en el área, de manera ostensible, más de mil armas como parte del impulso final para establecer el control de la ciudad de México. Durante el desorden que sobrevino, los distritos de Morelos y Cuernavaca fueron abandonados a su suerte, con muchas de las armas puestas en manos de los campesinos del lugar y otros miembros de las clases populares. Una serie de dirigentes populares surgieron en los pueblos, incluyendo a José Manuel Arellano en Tetecala, Guadalupe Rubio en Coatlán, Isidoro

75 AHDN, XI/481.3/5602: "Representación de la Comisión Central de hacendados de los distritos de Morelos, Cuautla y Cuernavaca, con motivo de la agitación producida entre los vecinos de los pueblos para obtener tierras", México, 24 de marzo de 1856. Este documento también lo reproduce L. Reina, op. cit., pp. 175-177.

76 AHDN. XI/481.3/5577: "Informe del prefecto de Morelos, José Granados, sobre disturbios en la hacienda Santa Inés", 17 de abril de 1856, ff. 1-2; "Orden de Guerra", 19 de abril de 1856. 
Carrillo en Xochitepec, Agustín Trejo en Tepoztlán y otros. Éstos se incorporaron al ejército del sur de Álvarez, pero cuando Alvarez se retiró después de renunciar a la presidencia en diciembre de 1855 , estos hombres permanecieron en los pueblos llamándose a sí mismos comandantes militares, aunque sin ninguna comisión o aprobación formal de parte del gobierno. ${ }^{77}$

De los reportes de Portilla se desprende que, ya en la campaña de Puebla, estos dirigentes y los batallones de la guardia nacional que habían organizado, constituían una forma de milicia popular en los distritos de Morelos y Cuernavaca. Ellos decían que actuaban por la causa de la libertad, aun cuando algunos de sus jefes no supieran leer ni escribir. Las armas se podían obtener con facilidad; en efecto, Portilla habla en algún momento de un activo mercado de armamentos. La campaña de Puebla trajo a estas mismas unidades de vuelta a la movilización activa, y una vez más bajo las órdenes de Álvarez. Cuando estas fuerzas regresaron a casa, encendidas por la reciente derrota infligida a los conservadores rebeldes, sólo estaban a un paso de desafiar a los terratenientes conservadores del lugar. ${ }^{78}$

A principios de mayo la movilización se había generalizado. Entre agosto de 1855 y finales de abril de 1856, calculaba Portilla, siete oficiales del gobierno, incluyendo alcaldes y miembros del cuerpo de seguridad, habían sido asesinados. La demanda de salarios más elevados se había extendido por todas las propiedades del área y, aunque la mayoría de los terratenientes parecían haber dado modestos aumentos ( $30 \%$ en la hacienda de Santa Inés, por ejemplo), en algunos casos los trabajadores, armados con machetes, pedían más. Según los terratenientes y los representantes del gobierno, los trabajadores involucrados en los incidentes también impedian ir a trabajar a los que sí querían hacerlo. En algunas áreas, los peones de las haciendas fueron a trabajar a punta de pistola, lo que hacía a esta acción disciplinaria imposible sin escolta militar. El incendio de los campos cañeros, que de hecho ocurrió en las haciendas de Santa Inés y Atlihuayan, fue la última amenaza en una época del año en que la principal parte de la cosecha estaba por recogerse. En estas circunstancias, parece que el único modo de realizar el trabajo en los campos era bajo la protección militar; al menos en Santa Inés esto fue lo que de hecho sucedió. ${ }^{79}$

Además de lo que claramente eran acciones de guerra en los sitios de trabajo de las haciendas, algunos hombres armados de los pueblos tomaron los campos reclamados por los grandes propietarios y comenzaron a cultivarlos con rifles sobre sus espaldas. Cuando se les preguntó, los agricultores admitieron que ellos eran de los pueblos y explicaron que las tierras en realidad pertenecian a las comunidades, lo que resulta sorprendentemente similar a la redistribución popular de la tierra de los zapatistas de casi medio siglo después; los habitantes de los pueblos y los soldados de la guardia nacional se mezclaban, volviéndose indistinguibles en la confusión de rifles y ropa campe-

77 AHDN /X1/481.3/5577: "Informes del general Nicolás de la Portilla sobre la situación en los distritos de Morelos y Cuernavaca", 23 de abril y 7 de mayo de 1856, ff. $7-9 \mathrm{v}, 17-18 \mathrm{v}$. La existencia de las guardias nacionales en la misma área durante el periodo 1846-1848, al menos algunas bajo la misma jefatura como veremos más adelante, implica por supuesto una historia más amplia de las bandas de la guerrilla. Véase p. 56.

${ }^{78}$ El análisis en este párrafo basado en ibid.

${ }^{79}$ Ibid. 
sina. El principal contraste entre la movilización de 1856 y la reforma zapatista posterior, haciendo a un lado la diferencia obvia del con* texto y de los acontecimientos, fue que en este primer periodo los habitantes de los pueblos y los trabajadores de las haciendas parecían estar unidos por una suma de causas comunes. ${ }^{80}$

La combinación y la mezcla de campesinos y miembros de la guardia nacional, junto con una (supuesta) unidad entre campesinos de las haciendas y los pueblos, hizo sonar la alarma para el gobierno nacional. Cuando Comonfort volvía de Puebla dos meses antes, los terratenientes de Morelos y Cuernavaca comenzaron a presionarlo acerca de los peligros de la guerra social y racial en la región. Resultaba conveniente, pues algunos agiotistas que ayudaron a pagar los costos de la campaña militar de Puebla habían estado comprando haciendas azucareras en el área desde la década de 1840 y comienzos de la de 1850. Por último, Portilla había sugerido desde finales de abril que el área padecía una gran ocupación militar, que los pueblos y villas fueran desarmados y que se formaran batallones de una "verdadera" guardia nacional, esto es, controlada desde arriba. Para el 10 de junio, el gobierno cedió ante las presiones combinadas. El ministro de Guerra ordenó a Portilla recoger las armas en todos los pueblos y haciendas de la región. La ofensiva contra el liberalismo popular había comenzado. ${ }^{81}$

La represión llevada a cabo Morelos entre junio y agosto de 1856 parece haber sido casi general, al menos como intento político. El gobierno central, lo mismo que la milicia local y los dirigentes políticos, fueron muy claros acerca de la necesidad de sofocar desde su origen la movilización. Más aún, no había ninguna duda de que la movilización era peligrosa en extremo; no sólo combinaba campesinos de las haciendas y los pueblos, civiles y miembros de la guardia nacional, sino que presentaba, mediante sus proclamas y actos, una interpretación del liberalismo que desafiaba la esencia de la elite y el control de los terratenientes en México. Sacrificándose a sí mismos en la lucha junto con otros de "el sur" para ayudar a los liberales a ganar poder dentro del gobierno, los campesinos de Morelos pensaban que se habían ganado el derecho a practicar el igualitarismo liberal.

Moldeados por las lecciones de pasadas batallas de los pueblos contra el gran Estado, en combinación con las experiencias de los campesinos del ejército de Álvarez en el sur, el liberalismo de los de Morelos no era el igualitarismo en el sentido de imaginar una sociedad sin clases; muy al contrario, la colaboración cruzada era la marca de toda la movilización, tanto por la cooperación de los lugareños más ricos con los pobres contra el gran Estado, como por la jefatura de oficiales de la pequeña burguesía de los pueblos en la guardia nacional organizada por Álvarez. ${ }^{82}$ Lo que mantuvo unida la coali-

so Ibid.

81 La sugerencia de Portilla está en AHDN, xI/481.3/5577, 23 de abril de 1856, ff. $7-9 \mathrm{v}$. La orden del ministro de Guerra está en el mismo expediente del 10 de junio de 1856, f. 34. La conexión entre los agiotistas y la campaña de Puebla la hizo Tenen-., baum, op. cit., especialmente en la p. 151.

${ }^{82}$ Sobre la jefatura de las guardias nacionales alvaristas en Morelos, véase AHDN, $\mathrm{xI} / 481.3 / 5577$, ff. 87-89, 17-18v; xI/481.3/5051, ff. 124-125. Acerca de la colaboración de ricos y pobres en los pueblos para dar la batalla al gran Estado, véase en especial, AGN, Gobernación, leg. 1144(1), exp. 1, 1865: "Exposición de varios vecinos notables de Tepoztlán al emperador", México, 28 de agosto de 1864. 
ción de fuerzas fue la visión de una sociedad justa que, mientras preservara las diferencias de riqueza y jerarquía, también daba a todos el derecho a la dignidad y subsistencia. Para garantizar esto, los campesinos debían renovar el acceso a la tierra de sus ancestros y sus derechos al agua, y a una forma de control democrática en la vida de los pequeños pueblos. En el centro de esta visión estaba la imagen de un campesino cultivando la tierra con un fusil a sus espaldas. El fusil era un símbolo dual: de la lucha que había dado a los campesinos el derecho legítimo a reclamar el suelo y de la violencia organizada que en última instancia aseguraría que este derecho fuera respetado. Pero mientras alguien respetara el derecho de todos a la dignidad y subsistencia, el grado de riqueza era, en si, motivo de hostilidad o recelo. ${ }^{83}$

Desde el punto de vista del presidente Comonfort, el ministro de Guerra, y los terratenientes locales, Juan Alvarez había hecho a su partido y a la nación muy poco servicio al jugar con tales formas de liberalismo igualitario, y especialmente al distribuir armas a las milicias populares - aun cuando fuera sólo con miras a controlar la ciudad de México-. El precio que el Estado liberal iba a tener que pagar para volver a poner a Morelos bajo su control, no valía los beneficios recibidos de las guardias nacionales de Morelos en agosto de 1856. En efecto,.conceptualmente era imposible para muchas autoridades estatales asociar las acciones contra las haciendas de mayo a junio de 1856 con la campaña de Puebla sólo unos meses antes. Nicolás de la Portilla, por ejemplo, aunque había proporcionado pruebas de las conexiones entre la guardia nacional, la campaña de Puebla y la subsecuente inquietud en los distritos de Morelos, se rehusaba a admitir que los miembros de la guardia nacional eran los mismos en ambos casos. A sus ojos, los hombres que ayudaron y apoyaron la discordia y la falta de respeto a la propiedad privada no eran los mismos que se habían distinguido en la lucha contra los rebeldes conservadores. Con el fin de resolver la contradicción, llamó a los soldados movilizados en Morelos "desertores" de los batallones de la guardia nacional. ${ }^{84}$

Pero no eran desertores; además de las autoridades estatales, Juan Álvarez mismo tuvo que enfrentar las implicaciones de este hecho para las futuras estrategias y políticas.

\section{La ofensiva contra el liberalismo popular: el caso de Tepoztlán}

Quizás el caso mejor documentado de la ofensiva del Estado contra los pueblos de Morelos a mediados de 1856 es lo que ocurrió en Tepoztlán. El 26 de junio, el general Portilla pidió ayuda al general Ángel Frías para desarmar la haciendas y los pueblos en las regiones de Morelos. Como era imposible estar en todas partes, decía Portilla, empezarían en Tepoztlán, donde él calculaba que habría alrededor de 600 armas. "La indiada se pondrá belicosa", predecía; así, era importante comenzar temprano, a las cinco de la mañana. El propósito final de la incursión, según Portilla, era desarmar a cien hom-

${ }^{83}$ Las fuentes citadas en la nota anterior hacen esto claro, lo mismo en el lenguaje que en la acción. Quizá el documento que hizo este punto tan dramático es la carta de Agustín Trejo, comandante de la guardia nacional de Tepoztlán, a Juan Álvarez: AHDN, XI/481.3/5577, ff. 87-89.

${ }^{84}$ AHDN, XI/481.3/5577, ff. $17-18 \mathrm{v}$. 
bres que cultivaban tierras de Felipe Gómez, asesinado por Ventura Gómez, quien ahora reclamaba la propiedad. ${ }^{85}$

Una vez que las tropas llegaron a Tepoztlán, sin embargo, las cosas no parecieron marchar según el plan. Después de arrestar a unos cuantos hombres que trabajaban en los límites del pueblo, incluyendo a Justo Sánchez, que era el teniente de la guardia nacional del lugar, la fuerzas del batallón de Frías llegaron al centro del pueblo con el aspecto de un verdadero ejército invasor. Según el alcalde del lugar, las tropas no respetaron a las autoridades locales, quemaron la casa de un ciudadano, saquearon algunas otras y, mientras intentaban arrestar a alguien en su propia casa, intercambiaron tiros que fueron respondidos por los hombres de la guardia nacional acampados en los cerros de los alrededores. Las versiones de lo que pasó después difieren amplia ente: el oficial invasor dijo en principio que Justo Sánchez haibla sido alcanzado por el fuego cruzado, aunque en la investigación que se siguió los testigos de la defensa declararon que Sánchez había sido muerto mientras intentaba escapar. ${ }^{86}$ Las autoridades, por otra parte, insistieron siempre en que Sánchez había sido baleado por un pelotón de fusilamiento. Cualquiera que ruese la verdadera versión $-\mathrm{y}$ los documentos no nos permiten establecerla claramente-, el comportamiento de las tropas de Tepoztlán el 28 de junio fue más allá de lo que se esperaría del batallón de un ejército que luchaba del mismo lado. En vez de esto, las tropas se portaron como una fuerza hostil de ocupación. ${ }^{87}$

Nada muestra esto con más claridad que la versión de los hechos dada por el alcalde, Pascual Rojas, en una carta que escribió a Juan Álvarez el 7 de julio. Según Rojas, apenas habían regresado de Puebla los de Tepoztlán, donde se habían sacrificado por la gloriosa causa del Plan de Ayutla, cuando las tropas federales entraron al pueblo el 27 de junio y arrestaron a un ciudadano (supuestamente Justo Sánchez), para llevarlo después amarrado "como a un facineroso" a la hacienda de Atlihuayan. A la mañana siguiente, los soldados entraron al pueblo y comenzaron sumariamente a buscar en las casas, alarmando a la población y causando uno que otro tiroteo. Estos incidentes, decía Rojas, sirvieron como pretexto mínimo para que el oficial a cargo ordenara la ejecución del prisionero, sin permitirle los oficios finales del cura y, dada la ineficacia de las primeras descargas, tuvieron que volver para acabar con él. Todo, concluye Rojas, ocurrió a mitad de la calle y con el prisionero rodeado de soldados; además de esta infortunada víctima, los jefes de las fuerzas invasoras también comenzaron a perseguir a otros oficiales de la guardia nacional y a los notables del lugar, muchos de los cuales se vieron forzados a esconderse. ${ }^{88}$

85 AHDN, XI/481.3/5577, "Copia de la carta del general Nicolás de la Portilla al general Angel Frías, sobre el desarme de Tepoztlán", 26 de junio de 1856, ff. 42-43.

${ }^{86}$ Acerca de la versión del oficial invasor, véase AHDN, $\mathrm{XI} / 481.3 / 5577$, "Informe del general Nicolás de la Portilla sobre los sucesos de Tepoztlán", Cuernavaca, 30 de junio de 1856, ff. 78-79. Acerca de la versión dada por los testigos en el juicio que se siguió, véase el mismo expediente, f. 91v.

87 Mi evaluación de todo el incidente, lo mismo que el resto de la información que se halla en el párrafo y que no cubre la nota 86 , proviene de una combinación de documentos en AHDN, XI/481.3/5577, ff. 42-43, 49-50v, 78-79, 86, 87-89.

${ }_{88}$ AHDN, XI/481.3/5577, "Carta del alcalde de Tepoztlán, Pascual Rojas, al general Juan Álvarez”, Tepoztlán, 7 de julio de 1856, ff. 87-89. 
La razón dada para la ejecución y las persecuciones, continuaba Rojas, era el asesinato de Felipe Gómez en enero de 1856, y escribía: "Nosotros estamos conscientes de que los crímenes deberían recibir castigo según la ley [pero] si está prohibido que los ciudadanos cometan crímenes, cuando los gobiernos los castigan deberían proceder a seguir un caso contra ellos y no ordenar su ejecución sin juicio, aun cuando la razón sea justa." 89 Pero quizá lo más interesante es que Rojas terminaba su carta refiriéndose a todos los buenos servicios que los ciudadanos de Tepoztlán habían hecho por la causa de la libertad. En seguida él hacía énfasis en que los tepoztecos no esperaban recompensa, puesto que todo lo hacían pór su propia voluntad y porque creían en las ideas por las que habian luchado; rogaba a Álvarez que usara su influencia en el gobierno central con el fin de obtener el perdón para los miembros de la guardia nacional y para otros notables que eran perseguidos. ${ }^{90}$

La preocupación de Álvarez acerca del incidente debe haber aumentado cuatro días más tarde, cuando recibió una carta del capitán de la guardia nacional de Tepoztlán, Agustín Trejo; de vuelta de su visita a Álvarez en La Providencia, Trejo se había visto obligado a esconderse porque lo perseguían las tropas federales que habían invadido su pueblo. Trejo insistía en su carta que cuando Gómez había sido asesinado, la guardia nacional estaba luchando en Puebla y era claro que no había posibilidad de implicarlo en el crimen. Terminaba su misiva informando a Álvarez que, a pesar de la orden de éste de no tomar las armas, los tepoztecos recibían órdenes del gobierno federal de hacer precisamente eso. ${ }^{91}$

Bastante extrañado Álvarez esperó todo un mes antes de actuar respecto a la cartas de Trejo y Rojas. Aun entonces, sólo envió una nota al ministro de Guerra en la que apoyaba a Trejo por ser un individuo respetable y pedía una explicación por el desarme de la guardia nacional de Tepoztlán. ${ }^{92}$ Esa carta hubiera sido más efectiva unos cuantos días después de los sucesos; un mes más tarde parecía un anticlímax. ¿Qué había pasado?

Sin duda, el hecho que alentó a Álvarez a no intervenir fue que los acontecimientos de Tepoztlán fueron motivados por un hambre de justicia tan profunda e históricamente antigua que, en última instancia, ni siquiera el liberalismo mexicano de tipo jacobino podía dar una respuesta sin desafiar el sistema existente de propiedad privada. Aquí es importante recordar que, a pesar de sus tendencias populistas y su radicalismo liberal, Juan Álvarez era, después de todo, un rico terrateniente. Una cosa era movilizar campesinos contra otros hacendados, en forma controlada y canalizada hacia un propósito político importante; pero una movilización generalizada, que amenazara con volverse independiente y que desafiara el solo concepto de la gran propiedad, eso ya era otra cosa. Como Álvarez había demostrado con su castigo a Arellano en 1848, en los momentos de una eventualidad nacional o política, los grandes hacendados tendían a cerrar filas. ${ }^{93}$

89 lbid., f. $88 \mathrm{v}$.

90 Ibid., ff. $88 \mathrm{v}-89$.

91 AHDN, XI/481.3/5577, “Carta de Agustín Trejo al general Juan Alvarez", Tepecoamilco, 11 de julio de 1856 , f. 86.

92 AHDN, XI/481.3/5577, "Carta de Juan Alvarez al ministro de Guerra, acompañando partes de Tepoztlán", La Providencia, 12 de agosto de 1856, f. 85.

93 Véase p. 56 de este trabajo. 
Quizá la manera de adentrarse en las profundidades de la emergencia de 1856 es observar los sucesos desde la perspectiva de los tepoztecos mismos. Desde el periodo colonial, el pueblo había estado resistiendo las invasiones de las haciendas vecinas en expansión. Estas invasiones se habían vuelto especialmente graves en la década de 1840 , resucitando viejas divisiones en el pueblo, al punto que una de las autoridades locales, al menos a los ojos del pueblo, traicionó a su comunidad llegando a un acuerdo formal con el propietario de la hacienda Oacalco. Localizada al este de Tepoztlán, esta propiedad había seguido un proceso de expansión económica en la década anterior y el dueño había estado invadiendo lentamente las tierras reclamadas por la comunidad. Al legalizar los límites existentes en 1849, el traicionero personaje había casi regalado a la hacienda algunos de los mejores terrenos. ${ }^{94}$

En la conciencia del pueblo los sucesos de 1849 tenían sus raíces en un pasado distante. Los habitantes de Tepoztlán justificaron su entrada a las tierras, pastura y otras fuentes de recursos, refiriéndose a su categoría de pueblo importante en el imperio azteca, y a la legalización de sus títulos de propiedad otorgados por Felipe II durante la colonia. Por tal razón los títulos que habían recibido en el siglo XVII eran preciosos para los tepoztecos conscientes de que, según la tradición oral, para la época de la independencia estos títulos se habían perdido ya dos veces. En cada caso la tradición decía que un lugareño traidor había sido el responsable; así que también desde esta perspectiva los sucesos de 1849 no eran nada nuevo. Pero cualquiera que fuese la realidad de las reclamaciones específicas hechas por la tradición del pueblo, es claro que jugaba un importante papel para aglutinar a la mayoría de los campesinos en su lucha contra un grupo especial e históricamente voraz de haciendas azucareras vecinas. ${ }^{95}$

Los años que van de 1849 al estallido de la revolución de Ayutla fueron extremadamente tensos y decepcionantes para Tepoztlán. En 1853, una de las leales autoridades del pueblo viajó a la ciudad de México con el pretexto de introducirse al comercio pero en realidad buscó y encontró los títulos originales de propiedad de Tepoztlán en el archivo nacional. El 6 de mayo fueron copiados y certificados, lo que produjo frenéticas celebraciones en el pueblo. Extáticos, los miembros de la comunidad demandaron una reconsideración legal de los límites establecidos en 1849; pero dada la legalidad del acuerdo de 1849, las autoridades decidieron en favor de la hacienda y amenazaron con multar a Tepoztlán con 900 pesos si traían de nuevo el caso a la corte. En este punto, la cuestión fue enterrada legalmente y los del pueblo se quedaron sin un centavo después de haber gastado todo cuanto tenían en abogados y cuotas en las cortes; pero quizá no fuera una coincidencia que el país estuviese en vísperas de la revolución de Ayutla. ${ }^{96}$

Un sector del pueblo, inspirado por su constante deseo de obtener justicia en la cuestión de la tierra, se unió a Alvarez en 1854-55. Ésta fue la gente que formó la guardia nacional de Tepoztlán, que luchó con Álvarez en 1855 y de nuevo en Puebla en 1856. Según la tradición

94 AGN, Gobernación, leg. 1144(1), exp. 1, 1865; “Exposición de varios vecinos y notables de Tepoztlán al emperador", México, 28 de agosto de 1864.

95 Ibid.

96 Ibid. 
del pueblo, todos estos hombres perecieron en la pelea, excepto dos que se convirtieron en los jefes de la resistencia del pueblo durante la guerra civil de 1858-61. A pesar de los servicios que los tepoztecos hicieron en favor de la causa liberal, los dirigentes liberales se olvidaron de Tepoztlán. Comonfort envió un ejército a ocupar el pueblo y a asesinar a su gente. Álvarez nunca reaccionó por las injusticias cometidas contra ellos y nunca trató el asunto de la tierra. Varios tepoztecos habrían de escribir una década más tarde:

Durante el gobierno de Álvarez y Comonfort, ni siquiera por los servicios realizados en favor de su causa vieron ellos con interés por las necesidades del pueblo; los mismos revolucionarios parecían olvidar las necesidades de los pueblos, y los desastres que nos sobrevenían aumentaron aún más con la caída de esta gente y la llegada al poder de Zuloaga y más tarde de Miramón. ${ }^{97}$

En efecto, la declaración que más nos dice acerca de lo que pasó en Tepoztlán se produce cuando identificamos y ponemos fecha al documento citado. Es una petición de un grupo de notables y de autoridades políticas de Tepoztlán al emperador Maximiliano en 1864. En ella, todavía están tratando de que les devuelvan las tierras que habían perdido en el traicionero arreglo de $1849 .{ }^{98}$ Eso es suficiente en cuanto a las promesas de liberalismo jacobino.

El segundo factor que limitaba el activismo de Alvarez en el incidente de Tepoztlán fue que a mediados de 1856 el balance de fuerzas había cambiado tanto en Morelos que la movilización campesina no podía servirle por más tiempo en su búsqueda continua de influencia en el ámbito nacional. El nivel de violencia, la fuerza de la alianza entre la guardia nacional y el campesinado, sólo podían enajenar a los potenciales aliados, ya fuera en sus lugares de origen o en otras partes del país. Por eso su mejor estrategia fue sentarse y observar la situación, en vez de involucrarse de una manera que pudiera perjudicar sus propias ambiciones.

Hay todavía una tercera razón por la que Alvarez no apoyó a Tepoztlán en 1856 y desde el punto de visita de la formación del Estado puede ser la más importante. Fue precisamente durante este año que el Congreso Constituyente votó el proyecto de Álvarez para agregar al estado de Guerrero los distritos de Morelos y Cuernavaca. Como resultó claro durante el debate acerca del proyecto en el Congreso, la historia de la movilización popular en Morelos -bajo los auspicios, se creía, de Álvarez mismo- predispuso a los delegados a pensar el asunto en términos de orden social: ¿El control sobre estos distritos aumentaría el poder de Alvarez en la región hasta el punto de que sería independiente del Estado central? ¿La anexión de esos distritos al estado de Guerrero alentaría la inquietud social y la anarquía en "el sur"? Prisciliano Díaz González, delegado del Estado de México, resume esta posición cuando alega que quitar a su estado el control sobre Cuautla y Cuernavaca "produciría rebelión, caos y anarquía". ${ }^{99}$ En tales circunstancias, no sorprende que Álvarez hubiera intentado mantenerse inactivo la segunda mitad de 1856. A la larga, tales consideraciones no ayudaron a la causa de Álvarez.

97 Ibid.

98 Ibid.

${ }^{99}$ Sinkin, "The mexican. . ", op. cit., p. 8. 
La propuesta de anexión de los distritos de Morelos y Cuernavaca a Guerrero fue derrotada en el Congreso por una votación de 48 a 33. ${ }^{100}$ Aún más interesante que la derrota misma, sin embargo, fueron los asuntos que brotaron en el curso del debate. Además de la cuestión del orden social, que estaba en toda discusión aun cuando no se mencionara específicamente, surgieron otras dos importantes.

La primera era el tema de la hacienda pública. Dado que la industria azucarera más importante del país estaba situada en estos dos distritos, ¿qué pasaría si Guerrero tuviera acceso a todos los impuestos fiscales generados en la región? Los representantes de Guerrero mantenían una posición contradictoria. Por un lado, sostenían que el Estado de México podía tener un excedente de fondos una vez que estos dos distritos pasaran a su estado, lo que parecía implicar que la riqueza generada en Morelos y Cuernavaca no era dramática en extremo; pero al mismo tiempo, decían que Guerrero necesitaba los recursos de Morelos y Cuernavaca para recobrarse de la devastación de la guerra, lo que implicaba exactamente lo contrario. Los representantes que se oponian a la propuesta estaban de acuerdo en que Guerrero necesitaba ayuda y recompensa por sus inmensos sacrificios por la causa de la revolución de Ayutla, pero alegaban que el país entero debía cooperar, en vez de penalizar al Estado de México quitándole su riqueza y sus distritos más florecientes. ${ }^{101}$ Por último, el debate hacía claro que las impresionantes cantidades de riqueza producidas por la industria azucarera de Morelos y la posibilidad de gravarla (en especial con los distintos impuestos por concepto de ventas recaudados del aguardiente de caña que se llevaba a la ciudad de México), eran consideraciones centrales en la lucha acerca de quién debería controlar los dos distritos.

La segunda cuestión surgida en el debate fue la situación del campesinado de Morelos y el papel que jugaron los terratenientes españoles en la opresión que sufrió la gente del campo en el área. Desde el principio Ignacio Olvera, representante de Guerrero en el Congreso Constituyente, alegaba que la anexión de Morelos y Cuernavaca a su estado era una cuestión política. La veía como una recompensa por los sacrificios realizados por los pueblos de "el sur" en favor de la libertad; ponía énfasis en que la condición de la gente mejoraría sin medida, ya que terminaría "la opresión feudal de los terratenientes". En respuesta a un delegado oponente, aportó más detalles acerca de los abusos cometidos por los terratenientes de los distritos azucareros de tierra caliente. El colega de Olvera, Rafael Jáquez, también representante de Guerrero, apoyó la línea política de este argumento al referirse a las peticiones de los pueblos y villas del área, en los cuales la opinión pública apoyaba la anexión de Guerrero. ${ }^{102}$

Dadas las preocupaciones de muchos delegados acerca de la cuestión del orden social, los argumentos políticos de los delegados de Guerrero fueron contraproducentes; sólo sirvieron para exacerbar la inquietud y el inextingible deseo de justicia social que corría bajo los sucesos de Morelos y Cuernavaca. Si a esto añadimos que la región producía, como en 1850, más de la mitad del azúcar del país (exclu-

100 Francisco Zarco, Historia del Congreso Extraordinario Constituyente (18561857), Fondo de Cultura Económica, México, 1956, p. 1121.

101 Ibid.

102 Ibid. 
yendo a Yucatán $)^{103}$ y que el control de este recurso pasaría a manos de un cacique populista con poder regional que no podía ser fácilmente controlado desde arriba, es sorprendente que la propuesta haya obtenido tantos votos positivos.

Lo más impresionante en la votación ocurrió el 15 de diciembre de 1856 , casi 48 horas antes de la incursión a las haciendas de Chiconcuac, Dolores y San Vicente. Esto explica en parte por qué periodistas, políticos y la comunidad diplomática, de inmediato tuvieron la idea de que, en cierta forma, la incursión era una revancha por la derrota en la votación. Como escribió el cónsul francés en México, Alexis de Gabriac:

parece que cuando el general Álvarez organizó una propuesta al Congreso para que los dos ricos distritos de Cuautla [Morelos] y Cuernavaca fueran anexados al estado de Guerrero, su agente aquí [la ciudad de México], el delegado [Rafael] Jáquez, al dejar la sesión después de la derrota de la propuesta, dijo en voz alta: "Muy bien, pero esta votación negativa les costará muchas cabezas". La amenaza había sido hecha. Además, se dijo que el mismo viejo pillo [Álvarez], cansado de toda la sangre y todos los crímenes, también declaró: "que los terratenientes de la tierra caliente habían intrigado contra la anexión al estado de Guerrero, pero que él se aseguraría de acabar con el último de ellos"(!) Esta bestia feroz ha tenido siempre el talento de ocultar sus crímenes. Los pintos realizan sus propuestas y con sólo una orden verbal suya, todos estos crímenes se cometen misteriosamente. ${ }^{104}$

Los conservadores mexicanos, la comunidad española, los terratenientes de Morelos, y una importante parte de los liberales moderados, todos compartían una profunda sospecha, no sólo acerca de las clases bajas, sino también de los jacobinos liberales del sur que habían ayudado y apoyado a los campesinos en su búsqueda de venganza.

\section{Nueva visita a Chiconcuac, Dolores y San Vicente: la incursión de 1856 desde la perspectiva histórica}

El 25 de septiembre de 1858, mientras la capital se encontraba bajo el control del gobierno conservador, cinco hombres fueron ejecutados por la incursión realizada en 1856 y por los asesinatos que ocurrieron en las tres haciendas de Pío Bermejillo. La ejecución misma fue bastante drámatica: por un lápso de dos horas los criminales convictos fueron presentados de dos en dos, con una fuerte guardia y muertos por estrangulamiento sobre una plataforma levantada cerca de la estatua de Carlos IV, en la calle de Bucareli, atrás de la Ciudadela. De los cinco que murieron, dos habían residido en las propiedades de Bermejillo: Trinidad Carrillo, que irabajaba la tierra en la hacienda de Dolores, y Camilo Cruz Barba, jornalero de Chiconcuac. Un tercero, Inés López, trabajaba a destajo cerca de la hacienda de San Nicolás, mientras que los dos restantes, Miguel Herrera y Nicolás Leite, eran agricultores de la región. Además, un sexto hombre había sido juzgado y condenado en ausencia: Isidro Carrillo, hermano de

${ }^{103}$ Periódico Oficial, 27 de julio de 1850.

104 L. Diaz, op. cit., vol. 1, p. 380. 
Trinidad, campesino de la villa de Xochitepec, que también había encabezado en el pueblo la guardia nacional creada por Álvarez. ${ }^{105}$

La lista de gente juzgada y ejecutada por los asesinatos múltiples y los robos de diciembre de 1856 proporcionan un punto de partida para reexaminar lo que pasó en esa fecha fatídica del 17 y 18 de diciembre, así como las repercusiones que continuaron durante el año de 1857. Los seis eran hombres humildes, probablemente representativos de la mano de obra rural en el distrito de Cuernavaca: campesinos del pueblo, residentes de haciendas que trabajaban de manera independiente y jornaleros que residían en los pueblos o en las grandes propiedades. Al menos, según el testimonio dado en el juicio, el hecho que provocó el incidente ocurrió cerca de dos meses antes de la incursión, cuando Nicolás Bermejillo, hermano del dueño, arrebató a Trinidad Carrillo la tierra que cultivaba en la hacienda de Dolores. Dos mujeres que vivían en la propiedad declararon haber oído a la esposa de Carrillo decir que éste había perdido sus tierras, después de que ellos dos habían servido durante tanto tiempo en la hacienda, y que "ella se consolaría cuando supiera que los españoles [de la hacienda] se revolcaban en su propia sangre".106 Se hizo la investigación, ya que la mujer no recordó este incidente sino hasta después de que ellos hubieron declarado; ${ }^{107}$ no sabemos si era verdad, pero al menos así se consideraba en el ámbito de Morelos en el periodo $1840-50$. Tenemos poderosas pruebas indirectas de que Dolores, lo mismo que las otras dos haciendas, estaba avanzando hacia grandes cambios bajo el control de Bermejillo a mediados de la década de 1850.

Es interesante señalar que Pío Bermejillo no adquirió las haciendas de Chiconcuac, Dolores y San Vicente sino hasta 1851. En ese momento entró en posesión de las propiedades, después de un reñido acuerdo de venta con el antiguo dueño, Anacleto Polidura, cuyas especulaciones con ellas lo habían llevado al borde de la ruina. En apariencia Polidura había sembrado caña en proporciones que no podía manejar con el equipo de molienda que existía en Chiconcuac y San Vicente durante los años de 1850 a 1851 ; entonces se vio forzado a desmantelar el molino de la hacienda de Dolores para usarlo como refacción del equipo de Chiconcuac. Además, no había agua suficiente para irrigar el incremento de hectáreas sembradas de caña de azúcar. El resultado final, en la segunda mitad de 1851, fue el desastre financiero. ${ }^{108}$

105 Sobre la ejecución y los antecedentes de los condenados, véase Bucheli, op. cit.; acerca de Isidro Carrillo como jefe de la guardia nacional de Xochitepec, véase AHDN, $\mathrm{XI} / 481.3 / 5577$, "Informe del General Nicolás de la Portilla sobre los sucesos en MoreJos y Cuernavaca", Cuernavaca, 7 de mayo de 1856, ff. 17-18v; y AHDN, XI/481.3/6867, "Oficio de Benito Haro al Ministerio de Guerra, sobre la aprehensión de algunos reos en el caso de San Vicente", Xochitepec, 11 de enero de 1857, f. 86v. Para la relación entre Isidro y Trinidad Carrillo, véase AHDN, xI/481.3/6781, "Solicitud de protección del súbdito español Pío Bermejillo y otros, con motivo de robos y saqueos cometidos por una gavilla de ladrones en las haciendas de San Vicente, Chiconcuac y Texcoco, Mex.", octubre, 1858.

106 Casasola, op. cit., p. 14.

107 Aguilar y Medina, op. cit., pp. 18-19.

108 José Fernando Ramírez, Informe en Derecho que pronunció en los estrados de la Exma. 2a. sala del Supmo. Tribunal de Justicia de la Nación. . por la testamentaría de don Miguel Ajuria en el pleito que le ha promovido D. Anacleto Polidura, sobre la legitimidad de la entrega de las haciendas de San Vicente, Chiconcuac y Dolores, Imprenta de Andrade y Escalante, México, 1859, pp. 6-8, 11-12, 29. 
Después de una breve administración interina de otro empresario que confiaba en adquirir dichas propiedades, Bermejillo obtuvo el. control de las tres haciendas. En principio, parece que continuó con la política de su predecesor, expandiendo principalmente el cultivo de la caña en Chiconcuac y San Vicente mientras arrasaba la hacienda de Dolores extrayendo desde refacciones hasta su caudal de agua para la irrigación. Incluso los trabajadores residentes en esta última hacienda a menudo recibían órdenes de trabajar en los campos de las otras dos; ${ }^{109}$ parece que en algun momento Bermejillo dio marcha atrás a su plan y gastó alrededor de 30000 pesos para volver a poner la hacienda de Dolores en su estado original, con maquinaria y suministro de otras formas de capital seguro. ${ }^{110}$ Mejor dicho, fue este cambio de estrategia lo que le produjo conflictos con los campesinos, con Trinidad Carrillo y su esposa, que habían residido en la hacienda de Dolores y tenían acceso a la tierra a cambio de realizar ciertos servicios; éstos, lo mismo que la gente que rentaba tierra mientras la hacienda permanecía inactiva, estaban condenados a convertirse en las víctimas del proceso de modernización. ${ }^{111}$

Eso fue lo que ocurrió en el contexto de especulación, modernizacion, expansión del cultivo de la caña de azúcar y cambios en las estrategias empresariales, cuyos efectos fueron dañinos sobre la población trabajadora de los pueblos y haciendas del área. Como resulta manifiesto al analizar la composición del grupo de hombres convictos, no sólo la gente de estas tres haciendas resultó afectada por el proceso. Hemos visto cómo ocurrían cosas similares por toda la región; mientras la hacienda reclamaba las tierras en disputa, los empresarios aumentaban el ritmo de trabajo y los residentes eran expulsados de sus parcelas. La incursión de 1856 fue una explosión de violencia momentánea y explicable, cometida por campesinos que habían enfrentado una década de ataques contra las vías de acceso a sus fuentes de subsistencia. Su reacción fue más amarga por el hecho de que las nuevas embestidas interrumpian una autonomía que fue creciente a partir de la independencia.

Pero la incursión a las haciendas de Bermejillo fue también la culminación de las promesas hechas por Juan Álvarez en Morelos, promesas que habían sido rotas cada vez más durante 1856. Compuesta por un grupo de gente similar a la que participó en la incursión de aquel año, la guardia nacional del pueblo, organizada y armada por Álvarez, había apoyado y defendido la causa liberal que les prometió tierra, subsistencia y justicia, primero en las batallas de 1855 para tomar la ciudad de México, y luego en la campaña de Puebla a principios de 1856. Para aumentar sus penas, sufrieron una ocupación militar a mediados de 1856 realizada por un ejército supuestamente liberal que en realidad los trató como a criminales

109 Sobre el conflicto de las propiedades entre Bermejillo y el otro empresario, Miguel Ajuria, véase ibid,, p. 28; Juan B. Alamán, Informe en Derecho pronunciado en los estrados de la Exma. Tercera Sala del Supremo Tribunal de Justicia de la Nación. . Por parte de D. Anacleto Polidura. . . en el pleito con la testamentaría de D. Miguel Ajuria. . sobre entrega legal y perfecta de las haciendas de S. Vicente, Chiconcuac y Dolores, Imprenta de J. M. Lara, México, 1860. Acerca de su proyecto inicial para las haciendas, véase Ramírez, op. cit., p. 31: Alamán, op. cit., p. 41.

110 Alamán, op. cit., p. 24.

111 La razón que dio Bermejillo para haber quitado a Trinidad Carrillo de la hacienda de Dolores fue que sus animales pisoteaban los campos de caña. Véase Aguilar y Medina, op. cit., p. 18. 
e intentó despojarlos de sus armas. Su muy respetado patrón y protectol, Juan Álvarez, parecía incapaz de hacer algo para ayudarlos, ya fur ra con su influencia en la ciudad de México o anexando los distritos de Cuernavaca y Morelos al estado de Guerrero. En este sentido, se comprende perfectamente que Isidro Carrillo, el único convicto participante de la incursión que escapó a la ejecución, fuera también un guardia nacional alvarista, comandante de Xochitepec, su pueblo. A los ojos del campesinado del lugar, quizá había llegado el tiempo de tomar el asunto en sus propias manos.

Quedaban todavía dos cuestiones importantes respecto a la incursión de diciembre de 1856: ¿Era en realidad contra los españoles?, y si así fuera ¿por qué? ¿Estaba Juan Álvarez directamente involucrado, tal como pensaban los terratenientes de Morelos, la comunidad diplomática y muchos políticos? Acerca del primer asunto, es interesante señalar que, mientras el abogado defensor - Luis Aguilar y Medina - intentaba lo que de seguro él mismo sabía era una defensa fútil de Trinidad Carrillo, hizo referencia al clima de odio contra los españoles que existía en Morelos a mediados de la década de 1850. Él alegaba que:

Alrededor de 1854 resulta claro, por la evidencia presentada en varios puntos del procedimiento, que existía, entre otras, una banda de "surianos" luchando contra Santa Anna. Varios españoles, entre los que estaba [Víctor] Allende [la primera víctima] y los Bermejillo, durante un almuerzo decidieron acabar con esta banda, que ya para ese momento era bastante grande y se localizaba en el lugar conocido como Los Hornos.

Según Aguilar y Medina, estos españoles fueron a Los Hornos, donde realizaron una matanza de mujeres, niños, hombres y ancianos, y dejaron "los cádaveres de muchas de las víctimas colgando en las casas de las haciendas de la tierra caliente que pertenecían a los españoles y que estaban ocupadas por ellos"'. Estos acontecimientos, y especialmente los cadáveres, "dejaron una marca indeleble en las haciendas que pertenecían a españoles, invocando sobre ellos [la ira de] los hijos del sur".

Si tal ocurrió realmente o no (además de la comprensible presentación dramática del abogado defensor, la única evidencia indirecta adicional que tenemos es un documento de 1855 que describe un encuentro mucho menos violento entre españoles y rebeldes en Los Hornos), el hecho de que podía ser un rumor lo suficientemente fuerte como para que fuera repetido por el abogado en la corte, significaba que era posible. ${ }^{112}$ Hay también mucha evidencia directa en los procedimientos de la corte sobre si los hombres involucrados en la incursión estaban conscientemente tratando de matar españoles; esto incluye, por ejemplo, el hecho de que algunos de los que fueron capturados en la hacienda de San Vicente se salvaron jurando que no eran españoles. ${ }^{113}$ No obstante, antes de escapar, Isidro Carrillo atestiguó que la misma banda había estado implicada en otros incidentes contra los españoles, incluyendo robos en las villas de San Vicente y Yautepec y en las haciendas de Acamilpa y San José, tres asesinatos en Yautepec y San José, y una incursión fallida a la ha-

112 Acerca de la versión de Aguilar y Medina del incidente en Los Hornos, véase ibid., pp. 41-42. Sobre el encuentro de 1855, véase Diario Oficial, 1855.

113 Casasola, op. cit., p. 59. 
cienda de Treinta. ${ }^{114}$ Finalmente, debemos recordar que todo esto ocurrió en el contexto de una hostilidad generalizada contra los españoles residentes en el área, tanto de parte del campesinado como de las tropas liberales, a causa de su prominente participación en la expansión de las haciendas y de su apoyo a la causa conservadora. Los incidentes contra los españoles continuaron en la región de Morelos durante la última parte de la década y se prolongaron durante los años sesenta. ${ }^{115}$

El último asunto que debemos considerar con respecto a la incursión es el grado de implicación de Juan Álvarez. Como hemos visto, muchos de los simpatizantes de los españoles daban por cierto que Alvarez había ordenado los asesinatos. Incluso la prensa liberal veía necesario justificar la inocencia de Álvarez, argumentando que aun cuando no había ninguna simpatía entre Álvarez y los españoles en Morelos y aun cuando hubieran sido los españoles los que pararon la anexión de Morelos y Cuernavaca al estado de Guerrero, esto no probaba que Âlvarez había planeado la incursión. ${ }^{116}$ En términos de la evidencia existente, de cierto no hay ninguna prueba directa de que Álvarez haya planeado el ataque a las propiedades de Bermejillo, ni ordenado ningún tipo de revancha más general contra los españoles; pero una serie de conflictos entre el caudillo suriano y las autoridades políticas y militares de Cuernavaca, que van desde el momento del incidente hasta enero de 1857, hicieron surgir algunas preguntas en las mentes de muchos liberales sobre la forma en que Álvarez había decidido hacer justicia.

El 29 de diciembre de 1856, el comandante militar del distrito de Cuernavaca, general Benito Haro, envió una carta a Juan Álvarez, en la que explicaba las presiones de los españoles sobre él y sobre el gobierno liberal para arrestar a los responsables de la incursión a San Vicente, Chiconcuac y Dolores. Continuaba diciendo que las evidencias parecían señalar a dos oficiales de la división de Álvarez, Juan Abascal y Juan Barreto; por eso le pedía a Álvarez que pusiera a los dos hombres en cuestión bajo la custodia del comando militar de Cuernavaca. ${ }^{117}$ Sin embargo, Alvarez consideró el arresto y enjuiciamiento de los dos oficiales como un asunto interno de su división; contestó a Haro al día siguiente, desde Puente de Ixtla, diciendo que estaría muy contento de enviarle a Barreto y Abascal si hubiera encontrado pruebas de su culpabilidad, pero que por el momento estaba convencido de su inocencia. Señalaba que era incorrecto sacrificar simplemente a dos hombres inocentes a causa de la presión que ejercían los enemigos del gobierno liberal; por tal razón había decidido comenzar su propio caso contra ellos para investigar independientemente cualquier evidencia de su participación en el incidente. ${ }^{118}$ A pesar de la presión creciente del gobierno central, Âlvarez se rehusó a cambiar de posición.

114 Aguilar y Medina, op. cit., p. 41.

115 Véase, por ejemplo, AHDN, XI/481.3/6267, 6268, 6388; ACDN, XI/111/2-405: Expediente de Francisco Leyva; AGN, Gobernación, 1a/858/(2)/1, exp 48, ff. 1-3.

116 Véase especialmente Grónica Oficial, 21 de diciembre de 1857 , p. 3.

117 AHDN, XI/481.3/6867, "Carta de Benito Haro al ministro de Guerra, transcr1. biendo oficio que dirige al general Juan Alvarez", Cuernavaca, 29 de diciembre de 1856 , ff. 65-65v.

${ }_{118}$ Ibid., "Carta de Benito Haro al ministro de Guerra, transcribiendo la nota de Juan Alvarez sobre Barreto y Abascal", 1 de enero de 1857, ff. 81-81v. 
En efecto, Alvarez y el gobierno liberal llegaron a un impasse; para este último el asunto era diplomático y jurisdiccional; cualquier retraso en procesar a los culpables empeoraría las tensiones con España, sobre todo en un momento en que el gobierno estaba ya enfrentando grandes dificultades con enemigos internos y externos; más aún, Alvarez no tenía la jurisdicción para juzgar a Abascal y Barreto; aunque era general de división no era comandante en jefe del ejército, y en todo caso los dos hombres no gozaban de privilegios para ser juzgados en una corte marcial. ${ }^{119}$ Por el contrario, para Álvarez el asunto era una cuestión de principios; para empezar, los liberales no deberían acobardarse por las presiones de sus enemigos y reprimir a los que habían luchado con lealtad en favor de la causa liberal; pero lo más importante era que él mismo no iba a sacrificar su prestigio como jefe revolucionario, presidente interino y primer magistrado de la república en un enfrentamiento de sus colegas liberales con un grupo de conservadores españoles; hasta donde él se daba cuenta, entregar a Barreto y Abascal a una corte regular, sería un insulto personal. ${ }^{120}$

En efecto, el conflicto fue un buen ejemplo de cómo las luchas acerca del federalismo tendían a entreverarse, y también a contradecirse, con las que se daban entre liberales moderados y radicales. En cuanto a Âlvarez, su capacidad para ganar y mantener a sus seguidores populares estaba íntimamente relacionada con la autonomía regional que obtuvo bajo el federalismo. Los moderados, temerosos del populismo de Alvarez lo vieron de la misma manera y por eso querían limitar su autoridad centralizando el poder. Hasta los puros, que podían haber simpatizado con el contenido social de la política de Alvarez, estaban conscientes del reto a la institucionalización representado por la autonomía del cacique regional. Al menos en este punto, los moderados y los jóvenes puros tendían a cerrar filas.

En febrero de 1857, sin embargo, la situación había ido más allá de lo que cualquiera esperaría; España había roto relaciones diplomáticas. A pesar de que Álvarez había arrestado a Barreto y Abascal y los había enviado bajo custodia a Acapulco, éstos escaparon; en la carta que escribió al ministro de Guerra informándole del escape, Juan Alvarez sonaba divertido y casi apologético: "Estos hombres, a los que en realidad quería salvar de ser sacrificados en el altar de las calumnias de sus enemigos, no sabiendo lo que es la gratitud, engañaron a sus guardias y escaparon de Acapulco el 10 de este mes [febrero]." Concluía diciendo que sólo quería que el presidente su-

119 Ibid., "Opinión de Juan de Dios Peza sobre que Alvarez entregue a los reos Barreto y Abascal", México, 31 de diciembre de 1856, ff. 27-29; "Carta del ministro de Guerra Juan Soto a Juan Álvarez", México, 31 de diciembre de 1856, ff.-33-34v; "Carta de Lerdo de Tejada, interino de Relaciones Exteriores, al ministro de Guerra, transcribiendo carta del encargado de negocios de SMC", México, 22 de diciembre de 1856, ff. 125-128; "Comunicación reservada del ministro de Relaciones Exteriores al ministro de Guerra, sobre el rompimiento de relaciones con España por los sucesos de San Vicente", México, 20 de enero de 1857, ff. 169-170v.

120 Ibid, "Carta de Juan Alvarez al ministro de Guerra, sobre los sucesos de Chiconcuac y San Vicente y revisión de Abascal y Barreto", Guerrero, 13 de enero de 1857 , ff. 22-24v; "Carta de Juan Alvarez al ministro de Guerra, quejándose de los procedimientos del General Benito Haro", Puente de Ixtla, 25 de diciembre de 1856, ff. 70-72; "Carta de Benito Haro al Ministerio de Guerra, transcribiendo carta de Juan Álvarez sobre Barreto y Abascal", Cuernavaca, 1 de enero de 1857, ff. 81-81v. 
piera esto, así que Comonfort no lo podía considerar rencoroso o injusto. ${ }^{121}$

En los meses que siguieron, los conflictos que rodearon la incursión a las propiedades de Bermejillo parecían haberse calmado. Diez días después de que escapó de Acapulco, Abascal fue muerto en un encuentro con las tropas del gobierno. ${ }^{122}$ Las negociaciones con los españoles se prolongaban y, en última instancia, improductivamente. Fue entonces, en junio de 1857, cuando los hombres capturados en Xochitepec cinco meses antes, que habían sido acusados de los asesinatos y los robos en las tres haciendas de Bermejillo, fueron por fin trasladados a la ciudad de México. Las autoridades esperaban que en la capital su juicio sería menos problemático y la posibilidad de escapar menos inmediata; ${ }^{123}$ pero la nueva publicidad que inevitablemente acompañó al traslado, en combinación con el comienzo de un nuevo juicio, parece haber incitado a Juan Álvarez a contestar por los cargos que contra él habían estado circulando en la prensa, entre los conservadores y la comunidad diplomática y, de modo más digno de atención, entre los terratenientes y autoridades del gobierno en los distritos de Cuernavaca y Morelos; el documento que redactó, una carta llamada "Manifiesto a los pueblos cultos de Europa y América", fue publicada en la prensa liberal de la ciudad de México el 26 y el 27 de julio de 1857.124 Pasa por ser la más apasionada defensa del derecho de los campesinos a la justicia social, escrita por un político de categoría nacional durante esos años. Por lo que dice y por lo que no dice, demuestra lo que el liberalismo jacobino pudo haber sido en México, y en última instancia por qué no pudo serlo.

Álvarez comienza su manifiesto citando, en su totalidad, una carta de Pío Bermejillo al cónsul español Pedro Sorela; aunque fechada el 25 de diciembre de 1856, este documento es obviamente para Álvarez la más representativa -y por consiguiente la más vulgarexpresión de los cargos contra él. Utiliza muchas páginas para establecer su legitimidad como comandante de las fuerzas que operaban en Morelos en 1856 y cita su correspondencia con el presidente Ignacio Comonfort que muestra que los dos generales están en los mejores términos. Estas páginas son interesantes porque revelan el grado de interés de Âlvarez por justificarse como jefe legítimo y establecer que no está en conflicto con los demás políticos liberales. La médula del documento viene después, explica por qué un ataque a los terratenientes españoles en Morelos y Cuernavaca podía haber sido autorizado; aunque por supuesto, detestaba tener que agregar cada vez que él, Allvarez, no había hecho tal cosa. ${ }^{125}$

121 Ibid., "Oficio de Juan Alvarez al ministro de Guerra, sobre los intentos de aprehender a Juan Barreto y Juan Abascal", La Providencia, 24 de febrero de 1857, ff. 15-15v. La cita textual está en el f. 15.

${ }^{122}$ I bid., "Oficio del comandante Benito Haro al Ministerio de Guerra", 23 de febrero de 1857, ff. 94-95.

${ }^{123}$ Ibid., "Comunicación del ministro de Justicia al ministro de Guerra, transcribiendo el oficio del magistrado José Mariano Contreras", México, 18 de junio de 1857 , ff. 114-114v. Acerca de cuándo fueron arrestados, véase ibid., "Oficio de Benito Haro al Ministerio de Guerra, sobre la aprehensión de algunos reos en el caso de San Vicente", Xochitepec, 11 de enero de 1857, ff. 86-87v.

124 L. Reina, op. cit., p. 172 n.

125 Juan Alvarez, "Manifiesto a los pueblos cultos de Europa y América" en $E l$ general don Juan Alvarez: Ensayo biográfico y selección de documentos, ed. Daniel Muñoz Pérez, Editorial Academia Literaria, México, 1959, pp. 441-470 (col. Reforma e Imperio, 2). 
La lista en que enumera los abusos cometidos por los hacendados españoles está dividida en dos categorias. La primera consiste en su participación política en los asuntos internos de México. Declara que en la guerra civil entre liberales y conservadores los españoles habían defendido consistentemente a los segundos, no sólo proveyéndolos con armamentos, municiones, víveres, dinero, caballos y hombres de sus haciendas, sino participando en la lucha como jefes de las bandas conservadoras que habían estado matando mexicanos por todo el territorio nacional. Alvarez escribe:

Bermejillo se atreve a preguntar qué operaciones militares tẹían que realizar mis tropas contra las indefensas haciendas, y yo le pregunto a él ¿de dónde venían los cabecillas conservadores Vicario, Cabareda (español), Lucio Loeza y otros, con sus fuerzas que llegaban en número a más de 1000 hombres, a llevar a cabo el ataque a Cuernavaca del 8 y 9 de diciembre en el último año? ¿Quién les dio armas, municiones, dinero, caballos y hombres si no fueron las haciendas? ${ }^{126}$

En particular, Álvarez escribe desde un nacionalismo ofendido que también manifiesta su personalidad. Era evidente que los españoles se habían involucrado en las cuestiones políticas que no les concernían en tanto extranjeros, y al hacerlo habían sido directa e indirectamente responsables por la muerte de muchos mexicanos; pero ¿el gobierno mexicano había hecho reșponsable a España entonces o la había llamado nación bárbara por tal razón?, y lo que era de igual importancia, ¿se había él comprometido en una vendetta personal contra los españoles a causa del crimen de alguien? La respuesta a ambas preguntas, en la mente de Álvarez era un sonoro "no", y esto colocaba a México y a los mexicanos en un plano superior, vis-à-vis con España y los españoles. ${ }^{127}$

Pero el corazón del argumento de Alvarez residía en la percepción de la forma en que terratenientes españoles habían abusado del campesinado de los distritos de Morelos y Cuernavaca. Hay más de 300 casos legales en los archivos del Estado de México, alega, que confirman la conducta criminal que estos hacendados españoles han observado con los trabajaciores rurales de la región. El lenguaje apasionado merece que se le cite ampliamente:

La mayoría de los hacendados y sus subordinados comercian y se vuelven ricos con el miserable sudor del infeliz trabajador; los enganchan como a esclavos, y hay deudas que alcanzan hasta la octava generación, siempre aumentando la suma y el trabajo personal [adeudado por] el pobre hombre y sirviendo de insulto a la humanidad, la razón, la justicia y al esfuerzo de los trabajadores cuyas fatigas y lágrimas se vuelven estériles.

La expropiación parece aumentar en vez de disminuir la codicia de algunos terratenientes; lentamente se apropian de las tierras privadas, lo mismo que las del ejido y que las tierras de la comunidad donde éstas existen, y entonces, con la más increíble falta de vergüenza, alegan que esas tierras son suyas sin presentar siquiera el título legal de propiedad; éste es suficiente motivo para que los pueblos clamen por justicia, protección y ayuda de la ley; pero las cortes son sordas a sus lamentos y peticiones y lo único que reciben los campesinos por haber reclamado lo que es de ellos, es la cárcel y la desgracia.

126 Ibid., p. 465.

${ }^{127}$ Ibid., especialmente pp. 467-470. 
Si alguien duda la verdad de esto por un instante, que lo diga públicamente en la prensa, para que yo satisfaga sus dudas publicando en cualquier periódico las innumerables quejas que he recibido, prueba de las miserables intenciones de los que se enriquecen con la sangre de la infortunada e infeliz gente mexicana.

Si yo quisiera contar la historia de las haciendas de los distritos de Cuautla y Cuernavaca, lo podría hacer muy fácilmente, y cada página se llenaría con 500 fragmentos de evidencia; entonces el público, las naciones y los escritores sin dignidad o decencia, verían las inicuas relaciones de negocios establecidas entre ladrones famosos y estos terratenientes. Pero lo repito, no deseo que la disputa que ya existe [se refiere al incidente diplomático entre España y México] se vuelva sangrienta por mi culpa, una disputa en que México y España han sido comprometidos sólo para beneficiar a cuatro hombres que merecen. . . cuando menos nuestro desprecio y desdén. ${ }^{228}$

En su libro sobre las rebeliones campesinas de México en el siglo xIx, Leticia Reina está de acuerdo cón el distinguido historiador del liberalismo mexicano, Jesús Reyes Heroles, en lamentarse de que Alvarez no haya escrito la historia de las haciendas de los distritos de Morelos y Cuernavaca. Con una historia así, escribe Reina, Álvarez "habría contribuido a la comprensión de las verdaderas causas de las revoluciones de independencia y de Ayutla en la región, lo mismo que al entendimiento de los motivos que empujaron a los pintos del sur a luchar a lo largo del siglo xix para que les devolvieran sus tierras a los pueblos". ${ }^{129}$ Estoy de acuerdo con Reina y Reyes Heroles en que tal historia habría sido un valioso documento, y también diría yo que era imposible que Alvarez la escribiera en las condiciones dadas en 1856-58; las razones de esta imposibilidad son más profundas de lo que Alvarez quiere admitir en su manifiesto.

Aunque es verdad que la exposición de los abusos de las haciendas habría empeorado el conflicto entre España y México, quizá hasta el punto de provocar una invasión española, también habría aislado a Alvarez por completo del resto del partido liberal. Comenzando con la campaña contra Puebla en enero, pasando por la ocupación y represión de las tropas liberales a los pueblos de Morelos a mediados del año y culminando con la votación en contra en el asunto de la anexión de Morelos y Cuernavaca al estado de Guerrero y con los acontecimientos de las haciendas de Chiconcuac, San Vicente y Dolores, lo que los sucesos de 1856 habían puesto en claro fue que la mayoría de los políticos e intelectuales liberales simplemente no pondrían la justicia social por encima del orden social. Los liberales moderados, por su parte, aprendieron con los conflictos de 1854-1857, que defender el sistema social contra las agresiones que venían de abajo los ponía del lado de.los conservadores. Estuvieron por completo de acuerdo con el conservador José Joaquín Pesado cuando escribió contestando directamente el manifiesto de Alvarez:

las doctrinas de disolución que se hallan difundidas hoy por todo el mundo llamado civilizado, inevitablemente producen amargos frutos. [ . . ] La soberanía del pueblo conduce a la desobediencia de toda autoridad; la libertad de prensa, la guerra perpetua contra los gobiernos, el crecimiento de la legislatura, la confusión y la degeneración de la ley,

${ }^{128}$ Ibid., pp. 464-465.

129 L. Reina, op. cit., p. 174. 
[. . ] y esa organización semibárbara de ejército, al que se da el irónico nombre de ejército de ciudadanos, es una amenaza perpetua a la paz pública y al bienestar de la familia. ${ }^{130}$

Pero hasta los liberales radicales estaban políticamente aislados a mediados de 1857. En repetidas ocasiones aprendieron la lección, pues con el fin de instituir cambios a largo plazo, debían de involucrarse en alianzas políticas indeseables. Por otra parte, para contrarrestar el poder combinado de conservadores y liberales moderados, tenían que ganarse el apoyo popular, lo que significaba agitar a las masas; esto no sólo era peligroso sino, como en el caso presentado por Alvarez, que la gente comprometida con las masas no era la nueva generación de intelectuales liberales, sino los viejos caudillos militares; precisamente aquellos que los reformadores centralistas estaban tratando de evitar. Fue entonces cuando los liberales jacobinos llegaron a un impasse en 1857. Dejando de lado ciertas declaraciones de tipo individual como el manifiesto de Álvarez y el proyecto personal de reforma agraria presentado al Congreso Constituyente por Ponciano Arriaga, los puros estaban obligados a hacer causa común con los moderados. ${ }^{131}$

Los dramáticos límites impuestos a la reforma social por miedo a la inquietud popular nunca fueron tan claros como en los efectos por los debates del Congreso Constituyente sobre la tolerancia religiosa. Comprometidos con una lucha a muerte contra el poder temporal de la iglesia católica, los liberales estaban más que deseosos de atacar las tierras de la Iglesia cuando tenía poco de suprimida su condición especial de religión protegida por el Estado. Según el delegado José María Lafragua, más tarde negociador por México en el incidente diplomático con España en 1857, esto fue porque "el estado de nuestra sociedad se halla por desgracia muy distante de lo que estaría si reformas tan importantes como ésta pudieran ser sugeridas sin correr un grave peligro"';132 y continúa más adelante Lafragua:

Aquí no hago una novela, señores, sino me refiero a un peligro que no es infundado, porque durante años la república ha estado amenazada con la guerra de castas. [. . . ¿ ¿Han olvidado los diputados a Yucatán, devorado durante años por una guerra fratricida? ¿Han olvidado el costo de la rebelión de la sierra [Huasteca] en 1849 y 1850 ? ¿Ignoran lo que está sucediendo en muchos pueblos del sur y Michoacán, y muy especialmente de Cuautla y Cuernavaca? Hoy supe, aunque no de manera oficial, de un levantamiento en Matamoros [Izúcar], no por razones políticas, sino por la tierra, en el que ha habido muchas muertes. Esto prueba, caballeros, que los indios están agitados y por esta razón es muy peligroso introducir ahora un nuevo elemento que será groseramente exagerado por los enemigos de la reforma con el fin de implicarnos en la anarquía más horrenda y absoluta. ${ }^{133}$

130 Ibid., pp. 173-174. Las cursivas son mías.

191 Acerca del análisis de la declaración de Ponciano Arriaga, véase Reyes Heroles, op. cit., vol. 3, pp. 595-603. Sobre la declaración misma, véase Zarco, op. cit., pp. 387.404

${ }_{132}$ Si se quiere conocer un argumento convincente acerca de que la votación sobre la tolerancia religiosa era en realidad una votación sobre la ley y el orden, véase Sinkin, The mexican constitutional..., op. cit., p. 7. Sobre la cita de Lafragua, véase Zarco, op. cit., p. 628.

133 Zarco, op. cit., p. 630. 
La agitación del indio debía evitarse a toda costa, y el precio que se pagaría era un liberalismo mexicano despojado de todo contenido social. Ya para 1856 esto era claro, y para 1857 un hecho consumado. En la confrontación acerca de cómo definir las reformas de 1855-58, los campesinos y el ideal jacobino habían perdido. Sucedido al final de un año que comenzó en Puebla, el incidente de diciembre de 1856 -que involucró al Estado mexicano, a Juan Álvarez, al campesinado de Morelos y a la ex madre patria - cristalizó de modo dramático las contradicciones que hicieron imposible un liberalismo más democrático. Esto fue meramente el "ensayo con vestuario"; todavía tomaría seis años de intervención extranjera más una década de conflictivo gobierno liberal, para que las implicaciones de este incidente se filtraran a través de toda la formación política y social de México; su culminación sería el porfiriato.

\section{Conclusiones}

Si volvemos al fatídico incidente de mediados de diciembre de 1856 , cuyas repercusiones convulsionarían al Estado mexicano durante los meses siguientes, una pregunta importante sigue sin respuesta: ¿En realidad Juan Âlvarez ordenó la incursión? Las evidencias probablemente nunca nos permitirán saberlo con seguridad, pero supongo que Alvarez no tuvo conocimiento previo del incidente. Una vez que esto pasó, no obstante, Álvarez se movió con rapidez para defender de la persecución del gobierno central a sus dos oficiales, Juan Abascal y Juan Barreto; lo que no prueba su implicación directa, sino el deseo de defender su autoridad, su prestigio y su autonomía como cacique regional, de cuya protección gozaban directamente los hombres bajo su control. Y lo que resulta interesante, Álvarez en realidad logró que esta política se mantuviera, pues ni los gobiernos liberales ni los conservadores fueron capaces de enjuiciar a sus tres hombres implicados en la incursión de $1856 .{ }^{134}$

Aun la forma en que fueron encausados los crímenes cometidos en las haciendas de Chiconcuac, Dolores y San Vicente nos proporciona una perspectiva en particular dramática del funcionamiento interno y las posibilidades del Estado mexicano a mediados del siglo xIX. Aunque incapaz de aglutinar una coalición que le permitiera de nueyo el acceso al poder en el ámbito nacional, Álvarez fue capaz - mediante la manipulación de su bloque de poder populista y regional entre 1855 y 1857 - de liquidar los intentos del gobierno central de establecer autoridad total sobre "el sur". Desde el punto de vista del Estado mexicano, esto puso en evidencia cuán poco hábiles habían sido los liberales para ir más allá de la regionalización del poder que se dio después de la independencia, y cuán escasa era en realidad la institucionalización. Cayendo en una y otra situación crítica en su lucha contra los conservadores, los liberales se habian visto obligados a confiar precisamente en la fuerza militar de caciques regionales como Álvarez para mantenerse en el poder. Al hacerlo, habían creado un equilibrio entre las viejas y las nuevas fuerzas sociales que frenaba cualquier ambición de diversificar, centralizar y expandir la autoridad del Estado. Esto, y no una conspiración, era la

134 Esto se aclara en una visión general de los documentos del caso, en especial en Casasola, op. cit. y Aguilar y Medina, op. cit.; AHDN, xI/481.3/6867, 4013 y 6781 . 
causa de la incapacidad del gobierno mexicano para responder a la presión de España para enjuiciar a los oficiales de Álvarez.

Cuando los conservadores tomaron la ciudad de México, en diciembre de 1858 , el proyecto liberal, tal y como había sido definido por la revolución de Ayutla, estaba en un callejón sin salida. Presionado por ambos lados, el Estado liberal había intentado seguir una ruta intermedia entre las demandas radicales de jacobinos y campesinos, y las presiones conservadoras del clero, de los terratenientes y de algunos sectores de las masas de indios y campesinos. Reflejando, como lo hizo, el pensamiento de los liberales progresistas acerca de la Iglesia y las tierras de las comunidades, de los monopolios y privilegios especiales, de la política económica y de un gobierno fuerte basado en el imperio de la ley, la Constitución de 1857 fue en verdad un gran logro del periodo 1855-58; pero los intentos liberales para estabilizar e institucionalizar un nuevo orden fallaron miserablemente. Sin el apoyo campesino, la mayoría de los liberales estaban incapacitados para forjar las alianzas políticas necesarias para canalizar la movilización campesina. La prueba última de este fracaso fue el arribo al poder de un nuevo gobierno conservador en 1858 y el hecho de que se enfrentaba a un país todavía fragmentado en múltiples bloques regionales de poder y a un campo efervescente todavía con protestas, radicales y conservadoras, por la política liberal.

El propósito principal de este trabajo, sin embargo, no ha sido medir de un modo positivista el "progreso" hecho por el Estado mexicano hacia la institucionalización. En vez de eso, al hacer una aproximación histórica y empírica al problema de la formación del Estado, he intentado mostrar cómo las estructuras de éste, en palabras de Maurice Zeitlin, "son productos históricos parcialmente contingentes", 135 en el sentido de que son creadas y modificadas por las luchas concretas dentro y entre las clases que existen en un periodo histórico y una formación social particulares. En el México del siglo xIx la forma del Estado no estaba dada, pero sí definida por las interacciones y confrontaciones entre una serie de clases y grupos. Varias fracciones de la clase dominante, de las potencias europeas interesadas en una dominación neocolonial y de un movimiento popular rural fuerte y diverso, luchaban entre sí para imponer su sello en el aparato estatal que surgía conforme avanzaba el siglo y con las reformas sucesivas de las estructuras del Estado heredadas de la colonia. Como he demostrado mediante el análisis de un incidente particularmente esclarecedor, los resultados de estas luchas no estaban dados a priori, pero es cierto que para la formación social mexicana el antecedente de las relaciones coloniales, de clase y raciales, junto con la manera específica de la confrontación y el conflicto, definieron las alternativas que eran posibles, y las que eran imposibles, para el Estado-nación mexicano.

Después de la "desadministración” del periodo colonıal tardío y de la regionalización del poder ocurrida a partir de la guerra de Independencia, México entró al periodo nacional con un Estado que principalmente constaba de tres instrumentos: el ejecutivo, el legislativo y el ejército. De éstos sólo el primero y el tercero poseían poder

195 Zeitlin, op. cit., p. 235. 
efectivo, mientras que el segundo servía para sancionar a los otros dos. A través de la primera mitad del siglo XIX, los frecuentes cambios de régimen y las constantes y destructivas luchas reflejaban los conflictos entre caudillos regionales para obtener la hegemonía en toda la nación, usando su base militar para subir a la silla presidencial mediante un pronunciamiento y entonces tratar de institucionalizar su posición. No obstante, hasta 1855 ni una sola fracción tuvo éxito en conservar el control sobre el ejecutivo durante un periodo significativo: una vez que la revolución de Ayutla llevó al poder a un partido liberal revitalizado y reconstituido, se desarrollaron debates y conflictos importantes acerca de cómo ampliar y reorganizar las estructuras del Estado con miras a estabilizar el nuevo orden mediante el imperio de la ley y no de los caciques militares.

En 1855 y 1856 los liberales se enfrentaron unos a otros dentro de las estructuras del Estado a causa de muchos asuntos que surgieron con su intento de crear un nuevo orden. Una variedad de clases y fuerzas sociales ejercieron presión sobre ellos, tanto en el Estado como en la sociedad civil. Esto incluía no sólo a los sectores conservadores de la clase dominante, a los campesinos conservadores y grupos indígenas, y a la iglesia católica, sino también a los sectores liberales de las clases populares, a los extranjeros residentes en México y a las representaciones diplomáticas oficiales de las potencias extranjeras. La presión estaba dirigida precisamente hacia aquellos mecanismos del Estado donde el poder se hallaba concentrado: el ejecutivo y los militares. Los miembros conservadores de la clase dominante, el clero y los extranjeros residentes, proporcionaron material y asistencia estratégica a las fuerzas conservadoras del ejército. Los campesinos, tanto liberales como conservadores, usaron la guardia nacional -institución parcialmente fuera del control del ejército regular - para formar sus milicias regionales, cuyas acciones presionaban al Estado en asuntos de interés local, como el acceso al culto religioso (conservadores) y a la tierra y la participación política (liberales y conservadores). Los representantes diplomáticos presionaban también por medio del ejecutivo y del ministro de Guerra para que se formularan políticas que fuesen congruentes con los intereses de sus naciones y de los extranjeros residentes en México. Por último, la legislatura se convirtió en la sede del conflicto entre las facciones liberales, cuando los jóvenes intelectuales y caciques militares pelearon por los intentos de los primeros de mediatizar el poder del ejecutivo y reducir la autonomía de las bases regionales de poder de los últimos. En estas condiciones la situación era muy fluctuante; es entonces, entre 1856 y 1858 , cuando los acontecimientos en Morelos fueron tan dramáticos y cruciales.

El control político y económico sobre los ricos y estratégicos distritos de Cuernavaca y Cuautla, en Morelos, se convirtió en un punto importante de conflicto entre los representantes de todas las clases y fuerzas sociales mencionadas antes. Durante la revolución de Ayutla el cacique militar Juan Alvarez, sacando partido del ya existente problema de la tierra en los pueblos de estos distritos y de su considerable influencia en "el sur", organizó las guardias nacionales de campesinos para respaldar su lucha por el poder en el ámbito nacional. Después del triunfo inicial de la revolución, los campesinos que constituían las guardias nacionales esperaban que el nuevo gobierno los recompensara y atendiera sus quejas acerca de la tierra y 
la participación política, en especial después de que lucharon en Puebla contra los conservadores; las guardias nacionales que volvían tomaron el asunto en su manos y usaron su control de la institución para realizar una ofensiva contra el gran Estado en la primera mitad de 1856.

A mediados de este año, la presión sobre el ejecutivo y el ministro de Guerra de parte de los terratenientes y de los españoles fue tan efectiva que produjo la ocupación militar de los pueblos de los distritos de Cuernavaca y Morelos; en ella el ejército regular se volvió contra las guardias nacionales rebeldes. Álvarez no apoyó a sus seguidores en este asunto porque se sintió amenazado en tanto terrateniente y porque todavía estaba interesado en negociar su influencia en la nación, un asunto para el cual los campesinos de Morelos se habían convertido en un riesgo. En este contexto, durante la segunda mitad de 1856 dos de los diputados del estado de Guerrero ante el Congreso intentaron usar la legislatura para ganar la partida a la elite de terratenientes y españoles de los distritos de Cuernavaca y Morelos, y presentaron el proyecto de anexión de estos distritos al estado de Guerrero. En la batalla legislativa que sobrevino por el control de los impuestos generados por estos ricos distritos azucareros y por el peligro de reforzar la autonomía regional de Alvarez contra los intereses centralizadores de los intelectuales liberales, Guerrero perdió.

La incursión a las haciendas de Chiconcuac, Dolores y San Vicente, sucedida tan sólo 48 horas más tarde, simbolizó y cristalizó tỏdas estas luchas ya existentes. En cierto sentido la reacción a la incursión en el siguiente año sirvió como un escenario adecuado en el cual se podía representar el muchísimo más amplio drama de la definición del carácter y la viabilidad del Estado liberal; incluía a todos los personajes: los campesinos y los guardias nacionales que parecen haberlo realizado; el cacique regional cuya participación directa fue enérgicamente subrayada por los terratenientes conservadores, españoles y miembros de la comunidad diplomática con el fin de desmantelar su poder nacional y regional; y un Estado liberal bloqueado que, aunque resistía las presiones de los terratenientes, conservadores y españoles, en efecto se encontraba exhausto e incapaz de ejercer su autoridad en el caso. Quizá resultara conveniente que el desenlace ocurriera cuando los conservadores se apoderaron del control del Estado, después de que las ambiciones de Álvarez por el poder nacional se habían acabado y después de que el presidente Comonfort puso fin a su vacilación característica entre los segmentos de la clase dominante y actuara prácticamente como presidente conservador interino.

Por tal razón los sucesos de 1850-58 hicieron especialmente evidente por qué la alternativa liberal, radical o democrática -a pesar de los deseos de un importante sector del campesinado y un pequeño segmento de la clase dominante- era históricamente imposible para el Estado mexicano. La herencia colonial de opresión clasista y racial, manifestada de mil modos en los sistemas de tenencia de la tierra, representación política, impuestos y muchos más ámbitos, tan mal disimulados que cualquier promesa de justicia estaba potencialmente cargada de violencia y podía producir una confrontación de grandes proporciones. Las intensas desigualdades presentes en la sociedad mexicana querían decir que la única manera de realizar reformas en realidad significativas, hubiera sido mediante la revolución 
social - un ataque al sistema existente de propiedad privada y una expansión radical del acceso popular al sistema político-, pero ni los liberales ni los conservadores deseaban hacerlo, aunque estaban interesados en la ley y el orden y en mantener la distribución básica de riqueza y privilegios.

Este análisis del Estado mexicano de mediados de siglo tiene implicaciones importantes para otros dos grandes asuntos que se interrelacionan: 1) la naturaleza del porfiriato y del autoritarismo mexicano en general, y 2) las causas de la revolución mexicana de 1910, específicamente de la revolución zapatista en Morelos. Hasta la década de 1970, la revolución de 1910 se consideró como una revolución social desde abajo, un movimiento popular de las masas campesinas que obtuvieron una gran reforma agraria y una nueva y más participativa forma de Estado. Cuando esta idea se combinó con el trabajo del prestigioso historiador y ex presidente del Comité Ejecutivo Nacional del Partido Revolucionario Institucional (PRI), Jesús Reyes Heroles, los acontecimientos de 1910-1920 se vieron como el regreso del país a la ruta inicialmente trazada por Hidalgo y Morelos en 1810 y reforzada más tarde por los dirigentes liberales del periodo 1855-76. En la historia moderna, grosso modo, la revolución representaba la culminación de la búsqueda de México del liberalismo social, la institucionalización y obtención del goce de las aspiraciones de justicia social del pueblo mexicano. El autoritarismo del porfiriato se destacó como una aberración en este contexto, como una interrupción momentánea del movimiento irrevocable de avance de México para convertirse en una nación poscolonial, moderna, democrática. ${ }^{136}$

Con las revisiones de los setenta nos movimos de un punto en el que se descalificaba al porfiriato a otro en el que se lo enfoca como la clave para explicar al México moderno. Los especialistas peinaron la política del porfiriato en busca de pistas del Estado posrevolucionario y encontraron continuidades por doquier. Aquí la víctima ha sido el liberalismo social de mediados del siglo xIx, visto ahora como un barniz que cubría las verdaderas intenciones liberales que eran la centralización del Estado y la destrucción de la propiedad comunal campesina. ${ }^{137}$ Uno de los propósitos de este trabajo ha sido ir más allá de estas posiciones en conflicto y reivindicar la realidad y legitimidad del liberalismo radical de mediados del siglo xIX sin perder las importantes percepciones revisionistas acerca del porfiriato y del autoritarismo mexicano.

Una perspectiva histórica del Estado mexicano en la década de 1850 supone una profunda explicación estructural de la persistencia del autoritarismo en México, una explicación que no necesite descalificar el liberalismo radical o la importancia del movimiento popular para entender el porfiriato. La herencia colonial de intensas desigualdades raciales y de clase, combinada con una larga y violenta tradición de movilizaciones en las clases bajas, dejó a las clases dominantes mexicanas sin alternativa, como no fuera la de reprimir constantemente las aspiraciones sociales y políticas de las masas. Investi-

136 Esta interpretación general está basada en el trabajo de Reyes Heroles, op. cit., vols. 2 y 3, y está discutida en L. Meyer, op. cit.

137 J. Meyer, Problemas campesinos. .., op. cit.; L. Meyer, op. cit.; Laurens B. Perry, Juárez y Diaz, machine politics in Mexico, Northern Illinois University Press, DeKalb, 1978; Sinkin, The Mexican reform. ., op. cit.; Tutino, op. cit. 
gaciones recientes han demostrado que hasta la independencia de México fue obtenida por criollos conservadores que habían estado implicados durante una década en la organización de la campaña realista de contrainsurgencia que daba la batalla a las guerrillas de base popular de José María Morelos y Vicente Guerrero. ${ }^{138}$

El Estado poscolonial mexicano nació con una mentalidad militar. En el curso del siglo xix nada pasó que alterara la realidad básica del papel del Estado que, definido dentro de las condiciones específicas de la formación social mexicana, era reprimir, aislar y derrotar los continuos desafíos que venían de abajo. La revolución de Ayutla en 1855, definida por las aspiraciones democráticas de un grupo de políticos liberales y caciques, fue una chispa de cambio en este esquema que duró un instante; pero debido a las razones ya detalladas, esta posibilidad no se llevó a cabo, por lo cual en la última parte del siglo las políticas porfirianas, las autoridades y los empresarios edificaron sobre una base autoritaria substancial ya existente.

El otro problema que sale a la luz con mi análisis del Morelos de mediados del siglo xIx es el origen del zapatismo. "Como una herida, la historia del país se abre en Anenecuilco", 139 reza la famosa frase de Gastón García Cantú. En efecto, para la mayoría de los que se dedican a estudiar la historia de México la revolución es una herida, una cuchillada que atraviesa la historia mexicana moderna, dentro y fuera de la cual deben fluir los grandes acontecimientos de los siglos xIX y xx; y más que nada, el zapatismo encierra las aspiraciones populares de la revolución. La existencia de un movimiento social tan amplio en Morelos entre 1848 y 1856, que unía a campesinos y guardias nacionales, pueblerinos y trabajadores de las haciendas proporciona un nuevo, más amplio y más interesante contexto del desarrollo de la ideología zapatista; la imagen del soldado campesino cultivando y defendiendo la tierra con un fusil a cuestas; el concepto de la auténtica democracia de los pueblos defendida por soldados civiles- que tenían la confianza de la población local; el intento de arrebatar a un gobierno nacional recalcitrante y temeroso algunas concesiones reales en lo que respecta al acceso a la tierra y a la democracia local; y, por último, la experiencia de haber sufrido una ocupación militar del ejército que se suponía que luchaba del mismo lado. Todas éstas son cosas que dan al zapatismo su dramatismo y matiz particulares con los que emerge a la escena histórica del Morelos de la década de 1850 .

La documentación respecto al movimiento de esta década aclara la profundidad histórica de las aspiraciones y la conciencia que yace bajo la revolución de 1910; pero también nos fuerza a preguntar ¿qué cambió entre 1856 y 1910 para permitir que estas aspiraciones fueran canalizadas con éxito hacia un movimiento social más amplio? $\mathrm{He}$ mos visto que en la década de 1850 simplemente no existía en la práctica la posibilidad de una alianza política entre los liberales radicales y los movimientos campesinos. Los liberales radicales ligados al campesinado, como Juan Alvarez, eran a su vez terratenientes o caciques que no se interesaban en una revolución social más ex-

138 Hamnet, Roots of insurgency. . . y "Royalist counterinsurgency. . .", ambas obras ya citadas.

139 Citado en Womack, Zapata and the mexican revolution, Alfred A. Knopf, Nueva York, 1968, p. 3. 
tensa. Los abogados radicales más jóvenes, como Ponciano Arriaga o Ignacio Ramírez, estaban interesados en constreñir a los caciques para institucionalizar el imperio de la ley y no tenían el poder social o político para organizar su propia coalición con el campesinado; por estas razones ningún segmento de clase socialmente significativo estaba dispuesto a hacer alianza con el campesinado.

John Tutino ha señalado recientemente que para 1910 habían ocurrido dos grandes cambios, ambos producto del porfiriato: primero, la comercialización de la agricultura, la especulación con la tierra y la colonización dieron como resultado nuevos niveles de expropiación agraria, convirtiendo las aflicciones rurales, ya comunes en algunas regiones, en un problema nacional; y segundo, la naturaleza del crecimiento económico en el porfiriato generó precisamente el tipo de segmento de clase que había estado faltando en la década de 1850 , es decir, una burguesía provinciana nueva y una pequeña burguesía que vio su camino hacia el poder nacional en la alianza con el movimiento popular. ${ }^{140}$ En cierto sentido Reyes Heroles estaba en lo correcto al ver la revolución de 1910 como la portadora del disfrute de las aspiraciones sociales de la década de 1850; lo que, sin embargo, no vio fue que además había una continuidad: frente a la renovada presión de un movimiento social aún más fuerte, la fracción burguesa recrearía un Estado militar, producto -como su antecesor - del hambre profunda y permanente de justicia social padecida por el pueblo mexicano.

\section{Agradecimientos}

La investigación en la que se basa este artículo fue realizada en México en 1984-1985 bajo los auspicios de la Fulbright Faculty Research Abroad Fellowship, con el apoyo adicional del Research Committee of the Graduate School de la Universidad de Wisconsin en Madison. Deseo agradecer a John Coatsworth, Friedrich Katz, John Womack Jr., Maurice Zeitlin y a dos revisores anónimos sus útiles comentarios del borrador de este trabajo, presentado como ponencia en octubre de 1986 en el encuentro de la Latin American Studies Association. 